\title{
ON THE SPECIES OF THE DUGESIA GONOCEPHALA GROUP (PLATYHELMINTHES, TURBELLARIA, TRICLADIDA) FROM GREECE
}

\author{
ELIZABETH J. DE VRIES \\ Institute of Taxonomic Zoology, University of Amsterdam, \\ P.O. Box 20125, 1000 HC Amsterclam, The Netherlands
}

\begin{abstract}
SUMMARY
Dugesia gonocephala is a species group, comprising numerous closely related species, which differ from each other in morphological and karyological aspects. In this paper known and presently described species, of the group from the eastern Mediterranean region, are reviewed. Hitherto the triclads of this region have been poorly known in comparison with their western counterparts. Yet there is a wealth of species in the area. Six well-delimited new species of the Dugesia gonocephala group are described and one further species is rescued from synonymy. The wealth of material available has also made possible an assessment of the taxonomic validity of many characters usually considered to be of importance within this difficult group.
\end{abstract}

\section{RÉSUMÉ}

Dugesia gonocephala est un groupe d'espèces, contenant de nombreuses espèces étroitement apparentées, se distinguant l'une de l'autre au point de vue morphologique et karyologique. Dans le présent article on passe en revue les espèces du groupe connues ou décrites comme nouvelles, de la région est-méditerranéenne. Jusqu'à présent les Triclades de cette région restaient mal connus en comparaison avec ceux occidentaux; néanmoins cette région se caractérise par son abondance d'espèces. On décrit six espèces nouvelles bien délimitées du groupe Dugesia gonocephala, et une autre espèce, auparavant considérée comme synonyme, est ici validée. L'abondance du matériel disponible a aussi créé la possibilité de vérifier la validité taxonomique de plusieurs caractères qui sont généralement regardés comme importants dans ce groupe difficile.

\section{INTRODUCTION}

This paper is one of a series leading towards a phylogenetic revision of the genus Dugesia sensu stricto, the type-genus of the family Dugesiidae. Distributed throughout the Old World this genus has been divided into a number of species groups or superspecies. The status of Dugesia gonocephala, the type-species of the genus, and supposedly the one best known, has previously been re-assessed (De Vries \& Ball, 1980).

The family Dugesiidae, of which Dugesia is the type-genus, was erected by Ball (1974a) who also made the first strict phylogenetic analysis of the group. Within the genus Dugesia as it was then known, Ball recognized a number of phylogenetic units which he gave subgeneric rank. One of the largest of these was the nominate subgenus, Dugesia, exemplified by Dugesia gonocephala and its allies.

In his phylogenetic revision, Ball (1974a) suggested that each of the subgenera recognized by him was worthy of generic rank but that elevation should await a thorough analysis of each group. This he has done for the genera Neppia (Ball, 1974b) and Spathula (Ball, 1977).

Now research is being carried out in Amsterdam in the hope of elucidating the phylogenetic status of, and phylogenetic relationships within, the subgenus Dugesia, especially the $D$. gonocephala group. Dugesia gonocephala s.l. is a superspecies, comprising a number of closely related species which resemble each other in external appearance, but differ from each other in internal anatomy and aspects of their karyology (Benazzi, 1955). The taxonomy within this group has proved to be complicated. This is because we are here dealing with a group of phylogenetically closely related species, of which some species have evolved more than others. There are several species that possess markedly different features in their copulatory apparatus, so that their identification poses no 
difficulties, whereas other species are very similar to each other, differing only in details, making it hard for the nonspecialist to distinguish them.

Species of the gonocephala group occur throughout the Old World. Several papers deal with members of the group from specific geographical areas. The Asiatic species were discussed by Ball (1970) and by Kawakatsu et al. (1976). Lepori (1951) has given an account of the western Mediterranean species known at that time, and Dahm (1971) has dealt with the African representatives. De Vries \& Ball (1980), and more recently De Vries (in prep.), have reassessed the status of $D$. gonocephala s. str. from European locations.

In order to obtain the necessary insight into the range of morphological variation within the group, a large number of species from different geographical regions were studied. As a result of this study it became apparent that the triclad fauna of a large area of the Mediterranean was still unknown. It is true that the Italian peninsula and the Italian islands are relatively well analysed, due to the work of Benazzi and his school (Benazzi, 1961), but the eastern Mediterranean, and in particular Greece and the Greek islands, are effectively "terra incognita" as far as their triclad fauna is concerned.

There are only two species of the subgenus Dugesia known from Greece, viz. Dugesia sagitta (Schmidt, 1861), from Corfu and Cephalonia, and Dugesia cretica (Meixner, 1928) from Crete. Unfortunately, Schmidt did not give a sufficient morphological description of $D$. sagitta, and subsequently this species was synonymized with D. gonocephala by Komarek (1925). There have also been reports on the karyology of two Dugesia species from Corfu (Ball, 1979), one of the species belonging to the subgenus Schmidtea, and the other to the subgenus Dugesia. Furthermore, there are some karyological data known from D. cretica (see Dahm, 1958; Benazzi \& Benazzi-Lentati, 1976). Apart from these data, the Dugesia species from the Greek region are unknown.

For all these reasons the opportunity was welcomed of studying an extensive triclad collection from the fresh waters of the Mediterranean region. The specimens were collected by Dr. H. Malicky of the Biological Station of Lunz, Austria, as a part of an ecological survey of the Mediterranean region. Apart from a number of species already known, the samples contained several new species of the $D$. gonocephala group from Greece and the Greek islands. In addition, new material from several Greek localities, which was already present in the Zoölogisch Museum, Amsterdam, has been studied. The new species are here described, their taxonomic position assessed and the validity of some commonly used taxonomic characters discussed.

Moreover, it is here felt that workers in this geographic area will benefit from a complete overview of the species of the gonocephala group occurring in this area. Therefore the descriptions of $D$. cretica and $D$. gonocephala s. str. (sensu De Vries \& Ball, 1980) are also included. In this way the paper serves as a synopsis of the entire subgenus in Greece.

\section{ABBREVIATIONS USED IN THE FIGURES}

$\begin{array}{lll}\text { ad adenodactyl } & \mathrm{mf} & \text { muscular fibres } \\ \text { af atrial fold } & \mathrm{mr} & \text { muscular ridge } \\ \text { at atrium } & \mathrm{mz} & \text { muscular zone } \\ \text { bc bursa copulatrix } & \mathrm{nz} & \text { nuclear zone } \\ \text { bs bursal canal } & \text { ov } & \text { oviduct } \\ \text { ca common atrium } & \text { pb penis bulb } \\ \text { dp diaphragm } & \text { pf penial fold } \\ \text { ed ejaculatory duct } & \text { pg penial glands } \\ \text { fd fold } & \text { pp penis papilla } \\ \text { go gonopore } & \text { sg shell glands } \\ \text { lu lumen } & \text { sv seminal vesicle } \\ \text { ma male atrium } & \text { vd vas deferens }\end{array}$

Drawings were made from camera lucida sketches. On each figure the scale bar represents $200 \mu \mathrm{m}$.

\section{MATERIALS AND METHODS}

For morphological study specimens were serially sectioned at $8 \mu \mathrm{m}$ intervals, stained by Mallory-Heidenhain, Phosphotungstic acid haematoxylin, Masson's trichome or Azan, and mounted in DePeX. On each slide the first section is on the upper left corner when the slide label is to the 
right. For sagittal and transverse sections the ribbons were arranged vertically, and for frontal sections the ribbons were arranged horizontally. The bulk of the material has been deposited in the Zoölogisch Museum of the University of Amsterdam (ZMA). Additional material was loaned by the Museum für Naturkunde der HumboldtUniversität, Berlin (ZMB).

\section{SYSTEMATIC SECTION}

All the species described in this paper belong to the $D$. gonocephala group and thus are closely related. This implies that they have several morphological features in common. These features are best expressed by reference to Dugesia gonocephala itself. In this way unnecessary repetition is avoided in the species descriptions, and in the latter the individual variations on the morphological "groundplan" will be given. To facilitate comparison a character table is provided as table I.

\section{Dugesia gonocephala (Dugès, 1830)} (Fig. 1)

Planaria gonocephala Dugès, 1830: 83.

Dugesia gonocephala; Girard, 1850: 265.

Euplanaria gonocephala; Hesse, 1897: 549.

Dugesia (Dugesia) gonocephala; Ball, 1974a: 376.

Description. - Living animals up to $18 \mathrm{~mm}$ long and $3 \mathrm{~mm}$ broad. Head of low triangular form with two eyes each consisting of a multicellular pigment cup containing many retinal cells. Supernumerary eyes, one or two on either side, sometimes occur. The colour of the dorsal surface is usually some shade of grey or brown, the pigment varying in intensity; sometimes the animals appear black to the naked eye. The ventral surface is somewhat paler than the dorsal surface. The marginally placed auricular streaks, just behind the eyes, are free of pigment.

The inner musculature of the pharynx comprises separate inner circular and longitudinal muscle layers. Typically the outer pharyngeal musculature also consists of two muscle layers, an inner circular and an outer longitudinal one, but in some members of the group there is an extra inner longitudinal layer in the outer muscle zone.

The paired ovaries are ventrally located just behind the brain. Typically the oviducts arise from the dorsal side of the ovaries from where they run ventrally caudad to the level of the copulatory apparatus. Here they turn dorsad and open separately into the vaginal area of the bursal canal just above the shell glands. The abundant vitellaria are distributed both dorsally and ventrally throughout the body length, the first follicles occurring just in front of the ovaries.

The follicular testes are numerous and dorsal, extending throughout the body length from a position just beside the ovaries.

The bursa copulatrix is lined with a high glandular epithelium. Stalked spermatophores often are to be seen in the bursa. The musculature of the bursal canal is of the reversed type, with inner, subepithelial, longitudinal muscles overlain with circular fibres. The epithelium of the bursal canal may be either infranucleate or nucleate. Typically, but not always, there is an extra outer layer of longitudinal fibres in the vaginal area forming an ectal reinforcement of the bursal canal. This feature occurs in all the species to be described below.

The penis comprises a muscular bulb embedded in the atrial wall and a free intromittent papilla. Characteristic is the diaphragm, of varied size and shape, which separates the intrabulbar seminal vesicle from the ejaculatory duct. The genital atrium may be divided or undivided.

Remarks. - Traditionally any freshwater planarian matching the above description has been assigned to $D$. gonocephala sensu lato. De Vries \& Ball (1980) and De Vries (in prep.), from a detailed review of the old literature and from studies of existing and new material from the original localities, have demonstrated that earlier concepts of $D$. gonocephala s. str. are misleading, and thus its geographical distribution is difficult to assess. These authors have given a new characterization of the Dugesia 


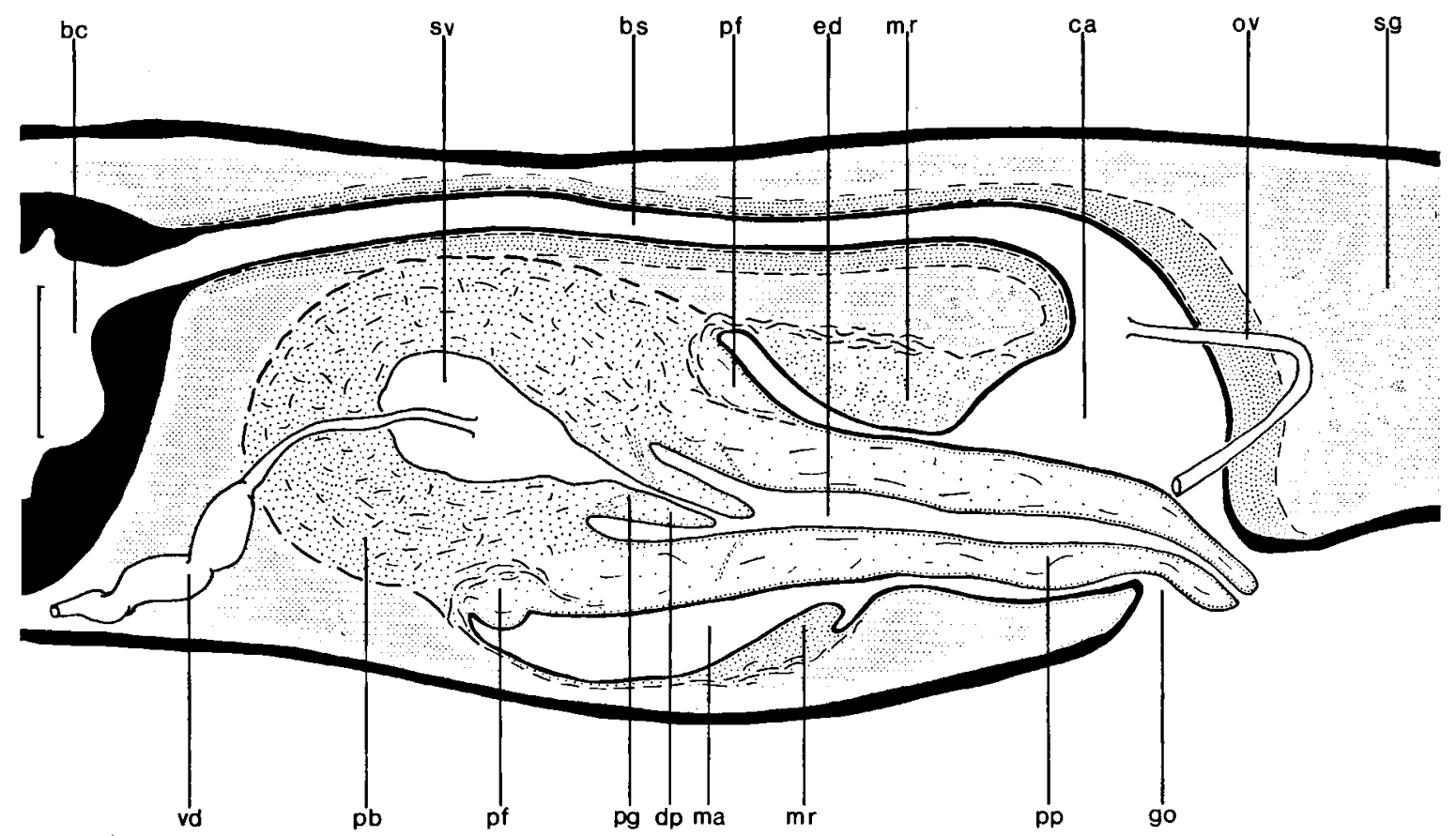

Fig. 1. Dugesia gonocephala s. str. (Dugès, 1830), diagrammatic sagittal reconstruction of the copulatory apparatus (ZMA V.P1.617.1).

gonocephala of Dugès (1830) in its restricted sense

In Dugesia gonocephala s. str. (Dugès, 1830) sensu De Vries \& Ball, 1980 (fig. 1) the penis bulb is very muscular. The penis papilla is of an elongate, conical shape, often protruding through the gonopore. A large, funnel-shaped diaphragm separates the seminal vesicle from the ejaculatory duct and this diaphragm often extends far into the penis papilla. At the base of the penis papilla there is a penial fold. The distinctness of this character depends on the state of contraction or relaxation of the penis papilla. However, the longitudinal muscle fibres separating the penis papilla and the penial fold are always distinguishable.

The atrium is divided into a male and a common atrium by a well-developed annular muscular ridge in the atrial wall. This muscular ridge is always present and is an important character for the identification of this species.

The pharynx often possesses an extra longitudinal muscle layer in the outer muscle zone, but this character is found to vary within populations (De Vries \& Ball, 1980).

Dugesia sagitta (Schmidt, 1861)

(Figs. 2 \& 9A)

Planaria sagitta Schmidt, 1861: 13.

Planaria gonocephala; Komarek, 1925: 323.

Dugesia gonocephala; Ball, 1979: 187; De Vries \& Ball, 1980 349 .

Type-material. - Messonghi River, just west of Messonghi, Corfu, Greece. Coll. I. R. Ball, 12 May 1978. Neotypes: four sets of sagittal sections (ZMA V.Pl.624.1-4), one set of frontal sections (ZMA V.Pl.624.5), one set of transverse sections (ZMA V.Pl.624.7), alcohol specimens (ZMA V.Pl.624).

Additional material. - Spring at Marbella Beach, Corfu, Greece. Coll. I. R. Ball, 13 May 1978. Two specimens in alcohol (ZMA V.Pl.625). One set of sagittal sections (ZMA V.Pl.625.1).

Stream near Mesaria, Corfu, Greece, $39^{\circ} 44^{\prime} \mathrm{N}$ $19^{\circ} 44^{\prime}$ E. Coll. H. Malicky, 11 June 1977 and 1 May 1979 (Korfu 1+2). Three sets of sagittal sections (ZMA V.Pl.626.1 + 4; V.Pl.627.1). One set of frontal sections (ZMA V.Pl.626.2) and one set of transverse sections 
(ZMA V.Pl.626.3), specimens in alcohol (ZMA V.Pl.626).

Corfu, Greece. Coll. J. Wilhelmi, June 1906. Nine specimens in alcohol. One set of sagittal sections in the Museum für Naturkunde, Berlin (ZMB Vermes 5385).

The original type-material from Corfu could not be located. In re-establishing this species I have selected the best preserved material for the neotype and thus the type-locality is here restricted to the Messonghi River, Corfu, Greece. This is a large, fast-flowing and permanent river, where the planarians were exceedingly abundant when originally collected.

Description. - Living specimens up to $10 \mathrm{~mm}$ long and $3 \mathrm{~mm}$ wide and grey- to olivebrown in colour.

The ovaries are located ventrally in the area of the seventh intestinal branch. Many large oocytes are present, and meiotic phases are to be seen in a number of specimens.

The testes begin just in front of the ovaries. The vasa deferentia form small extra-bulbar or false seminal vesicles before entering the penis bulb to open into the seminal vesicle very close to the diaphragm.
The bursal canal runs slightly to the left of the copulatory complex before opening into the atrium. The lumen of the bursal canal is lined with an infranucleate epithelium. The ectal vaginal reinforcement extends about halfway to the bursa copulatrix.

The penis bulb is weakly muscular, and encloses a slightly lobed seminal vesicle. The lumen of the seminal vesicle is lined with a glandular epithelium; in some specimens these granular glands have discharged their contents into the lumen of the seminal vesicle. The rounded conical penis papilla protrudes into the undivided atrium and is only weakly muscular. The base of the penis papilla is surrounded by an asymmetric penial fold, which is always more developed dorsally than ventrally, or even totally absent from the ventral side. The ejaculatory duct follows a central course through the penis papilla and opens at its tip. The seminal vesicle is separated from the ejaculatory duct by a well-developed valve-like diaphragm.

A characteristic feature of the male copulatory apparatus is its extremely glandular nature. The penial glands surround part of the seminal vesicle inside the penis bulb, in places

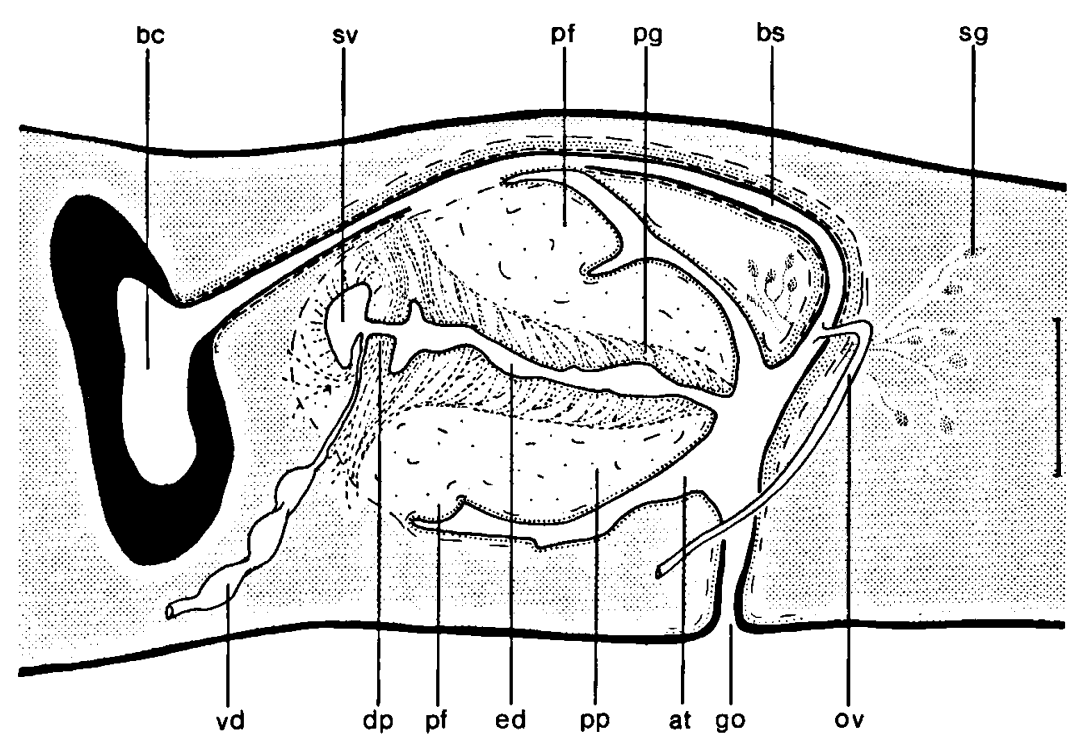

Fig. 2. Dugesia sagitta (Schmidt, 1861), diagrammatic sagittal reconstruction of the copulatory apparatus (ZMA V.Pl.624.1). 
penetrating into the surrounding tissue. From the penis bulb the glands extend into the penis papilla where they narrow down to form a glandular zone surrounding the ejaculatory duct. The whole glandular zone is $\mathrm{V}$-shaped in median sections. The glands along the ejaculatory duct are more granular than those in the diaphragm, often staining differently.

Karyology. - Material from the neotypelocality has been analysed by Ball (1979). All the specimens were sexual diploids, $2 n=2 x=16$, with only metacentric chromosomes.

Remarks. - Komarek (1925) declared the Planaria sagitta of Schmidt to be conspecific with D. gonocephala (Dugès) and this view has been accepted without exception (Kenk, 1974). D. sagitta differs from $D$. gonocephala s. str. in its extremely weak penial bulb, its valve-like diaphragm, and the cone of prominent glands within the penis. Diagnostic features of $D$. gonocephala s. str., such as the funnel-shaped diaphragm, elongate penis papilla, and annular ridge of muscles in the atrial wall, are absent from the Corfu material. Therefore, I consider Schmidt's species to be valid.

The visibility of the characteristic penial glands depends on the staining, which in its turn is greatly influenced by the type of fixative used. Nevertheless, all the recently preserved material, fixed in different fixatives, clearly shows the glandular areas which are important characteristics of the species. Even the material collected in 1906 by Wilhelmi, which proved to hold the stain with difficulty, showed the specific glandular areas, albeit less conspicuously. In this specimen from Wilhelmi's collection, the penis is very extended, probably because of the fixative used, so that the penial fold is not very distinct.

Schmidt (1861) recorded D. sagitta also from Cephalonia, but the present study strongly suggests that this record concerns a different species ( $D$. aenigma $\mathrm{n}$. sp.). The name $D$. sagitta is here reserved for the species from the first mentioned locality, Corfu.
Dugesia cretica (Meixner, 1928)

(Fig. 3)

Euplanaria cretica Meixner, 1928: 585.

Euplanaria (Euplanaria) cretica; Kenk, 1930b: 292.

Dugesia (Dugesia) cretica; Ball, 1974a: 376.

Material. - In stream near Kakopetros, Crete, Greece, $35^{\circ} 24^{\prime} \mathrm{N} 23^{\circ} 45^{\prime} \mathrm{E}$. Coll. H. Malicky, 13 May 1979 (K.611). Sagittal sections on four slides (ZMA V.Pl.648.1), specimens in alcohol (ZMA V.Pl.648).

Brackish-water spring, Georgiupolis, Crete, Greece, $35^{\circ} 22^{\prime}$ N $24^{\circ} 15^{\prime}$ E. Coll. H. Malicky, 28 September 1972 (K. 237). One set of sagittal sections (ZMA V.Pl.651.1) and two sets of frontal sections (ZMA V.PI.651.2-3), specimens in alcohol (ZMA V.Pl.651).

Stream near Topolia, Crete, Greece, $35^{\circ} 25^{\prime} \mathrm{N}$ $23^{\circ} 41^{\prime}$ E. Coll. H. Malicky, 3 October 1972 (K. 258). One set of sagittal sections (ZMA V.Pl.653.1), alcohol specimens (ZMA V.Pl.653).

Streamlet near Karia, Tinos, Greece, $37^{\circ} 34^{\prime} \mathrm{N}$ $25^{\circ} 10^{\prime}$ E. Coll. H. Malicky, 8 June 1979 (Tinos 4). Two sets of sagittal sections (ZMA V.P1.652.1-2), one set of frontal sections (ZMA V.Pl.652.3), one set of transverse sections (ZMA V.Pl.652.4), specimens in alcohol (ZMA V.P1.652)

The type-material was collected by $\mathrm{H}$. J. Wichmann in May 1927 in a stream near Meskla, Theristo, on Crete, Greece, and is now in the collections of the U.S. National Museum, Washington D.C.

Description. - The preserved animals reach a length of $8 \mathrm{~mm}$ and a width of $2 \mathrm{~mm}$, a copulatory apparatus is even found in animals which are relatively small $(5 \mathrm{~mm})$.

The ovaries are normal in size and shape and positioned in the area of the fifth intestinal branch. The oviducts arise from the dorsal wall of the ovaries.

The testes begin at the level of the ovaries and are normally developed. The vasa deferentia form small extra-bulbar seminal vesicles before entering the penis bulb to open into the seminal vesicle.

The bursal canal runs to the left of the penis and opens from a posterior position into the atrium, thereby dividing the atrium in a maleand a common atrium. The lumen of the bursal canal is lined with a nucleate epithelium. In the vaginal area a well-developed layer of longitudinal muscles forming an ectal reinforce- 


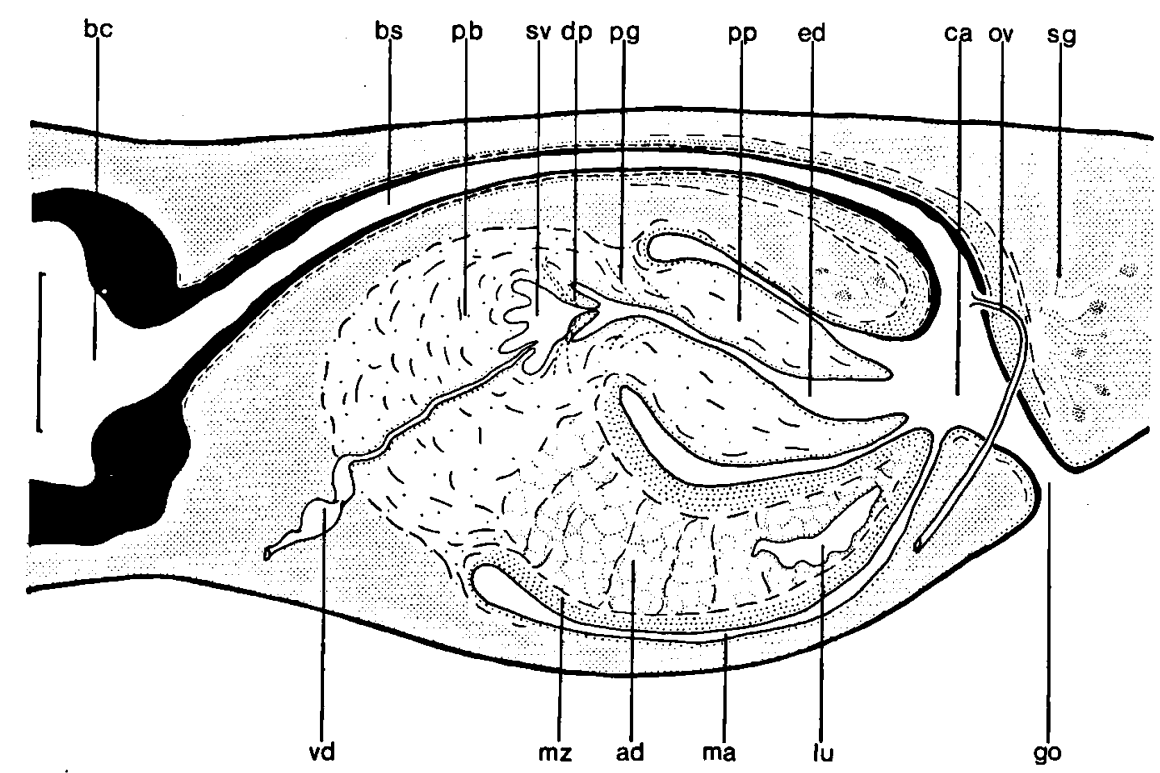

Fig. 3. Dugesia cretica (Meixner, 1928), diagrammatic sagittal reconstruction of the copulatory apparatus (ZMA V.Pl.648.1).

ment can be seen, extending about halfway to the bursa copulatrix.

The penis consists of a muscular penis bulb enclosing a small and lobed seminal vesicle, and a muscular conical penis papilla. The ejaculatory duct runs centrally through the penis papilla and opens at its tip. A funnelshaped diaphragm separates the ejaculatory duct from the seminal vesicle. Some penial glands are present. A large finger-like muscular glandular organ or adenodactyl, arises from the base of the penis bulb ventrally of the penis papilla and protrudes into the atrium alongside the penis papilla. In all the specimens studied, the adenodactyl was positioned ventrally of the penis. In most of the specimens the papilla of the adenodactyl extended somewhat to the left of the penis papilla, whereas in one specimen it was found to protrude into the atrium slightly to the right of the penis papilla, so that the papilla of the adenodactyl seems to be a structure of limited flexibility. The adenodactyl is as large as and sometimes even larger than the penis papilla, its tip often entering the vaginal area of the bursal canal. The adenodactyl consists of glandular parenchymatic tissue surrounded by a double layer of muscles, viz. a distinct layer of inner longitudinal muscles, overlain by a thick outer layer of circular muscles. A lumen is present in the posterior part of the adenodactyl; in some specimens this lumen may be filled with secretion.

Karyology. - There are two different chromosome numbers known of $D$. cretica: Dahm (1958) has reported a chromosome number of $2 n=2 x=16$ in one individual of $D$. cretica, whereas Benazzi \& Benazzi-Lentati (1976) have recorded a karyotype consisting of 16 bivalents and some univalents in different specimens which they attributed to $D$. cretica (cf. remarks on $D$. minotauros).

Remarks. - The first detailed morphological description was given by Kenk (1930a). The material studied here conforms with Kenk's description in most aspects, but is found to differ from it in that here the atrium is described as being divided, whereas Kenk describes it as undivided. However, as will be pointed out below, the division of the atrium is a difficult diagnostic character, and has to be dealt with cautiously. 
Furthermore,-Kenk records the papilla of the adenodactyl ventrally to the right of the penis papilla, whereas in the majority of the material studied here, it is situated ventrally to the left of the penis papilla. It seems that the papilla of the adenodactyl protrudes into the atrium in a slightly flexible way, although it invariably arises from the penis bulb ventrally of the penis papilla.

D. cretica is known with certainty to occur on the Greek islands Crete and Tinos (De Vries, in prep.). There are records of this species from Rumania (Natasescu, 1972), Turkey (Kosswig \& Battalgil, 1942; 1943), Greece and Persia (De Beauchamp, 1953) and Israel (Bromley, 1974), but from the given descriptions it is doubtful whether these records refer to $D$. cretica or to a closely related species.

De Beauchamp (1936) recognized two Persian forms which he thought attributable to $D$. cretica, viz. B and C, A being the original species from Crete. Livanov (1951) however, has demonstrated that form $\mathrm{C}$, which does not possess an adenodactyl, is a distinct species: $D$. iranica Livanov, 1951. Form B, which possesses an adenodactyl of variable size and without a lumen, is most likely a different species. It is clear that these forms described from outside Crete and Tinos are in need of taxonomic clarification.

Dugesia malickyi sp. nov.

(Figs. 4 \& 9B)

Type-material. - Spring, Polydroson, Greece, $38^{\circ} 36^{\prime}$ N 22 ${ }^{\circ} 34^{\prime}$ E. Coll. H. Malicky, 30-31 May 1976 (M. 23). Holotype: sagittal sections on five slides (ZMA V.PI.635.1). Paratypes: One set of sagittal sections (ZMA V.PI.635.2), one set of frontal sections (ZMA V.PI.635.3), one set of transverse sections (ZMA V.P1.635.4), alcohol specimens (ZMA V.Pl.635).

Etymology. - This species is named after Dr. Hans Malicky, who collected most of the material described in this paper.

Description. - The preserved specimens are very large, reaching a length of up to $13 \mathrm{~mm}$ and a width of up to $3 \mathrm{~mm}$.
The ovaries, which are positioned between the fourth and fifth intestinal branch, are large though not hyperplastic; many normal oocytes were observed.

The testes contain many spermatogonia but also ripe spermatozoa. The vasa deferentia form small false seminal vesicles and then bend up before recurving downwards to open from a dorsal aspect into the seminal vesicle.

The bursal canal runs slightly to the left of the copulatory apparatus and opens into the atrium, which is divided into a male and a common atrium. The bursal canal is lined with a nucleate epithelium, overlain by a distinct layer of longitudinal muscles surrounded by circular muscles. In the vaginal area the bursal canal widens and becomes very spacious, the surrounding circular muscles are more developed and some outer longitudinal fibres can be seen, extending to about one third of the distance to the bursa. Surrounding the musculature of the bursal canal there is a distinct zone of nuclei. In one specimen a spermatophore is present in the bursa.

The penis consists of a muscular, rigidlooking, conical papilla and a penis bulb, which is formed by a thin layer of muscles surrounding the seminal vesicle. The ejaculatory duct runs slightly ventrally through the penis papilla, but opens at its tip. A glandular valvelike diaphragm separates the ejaculatory duct from the seminal vesicle. Dorsally and laterally to the left is a dorsal extension of the penis papilla, which protrudes slightly into the atrium. The tissue inside this structure or fold, is a little more parenchymatic than that in the penis papilla and at the atrial side it is surrounded by a thin layer of muscular fibres, of which the nuclei can clearly be seen. A few sparse muscle fibres can be seen running from the penis bulb to the fold, no glands are present. The dorsal side of the penis papilla is more muscular and glandular than the ventral side.

Remarks. - Characteristic of this species is the strong muscularity of the bursal canal, especially in the vaginal area. In contrast the male copulatory organ is but weakly muscular. 


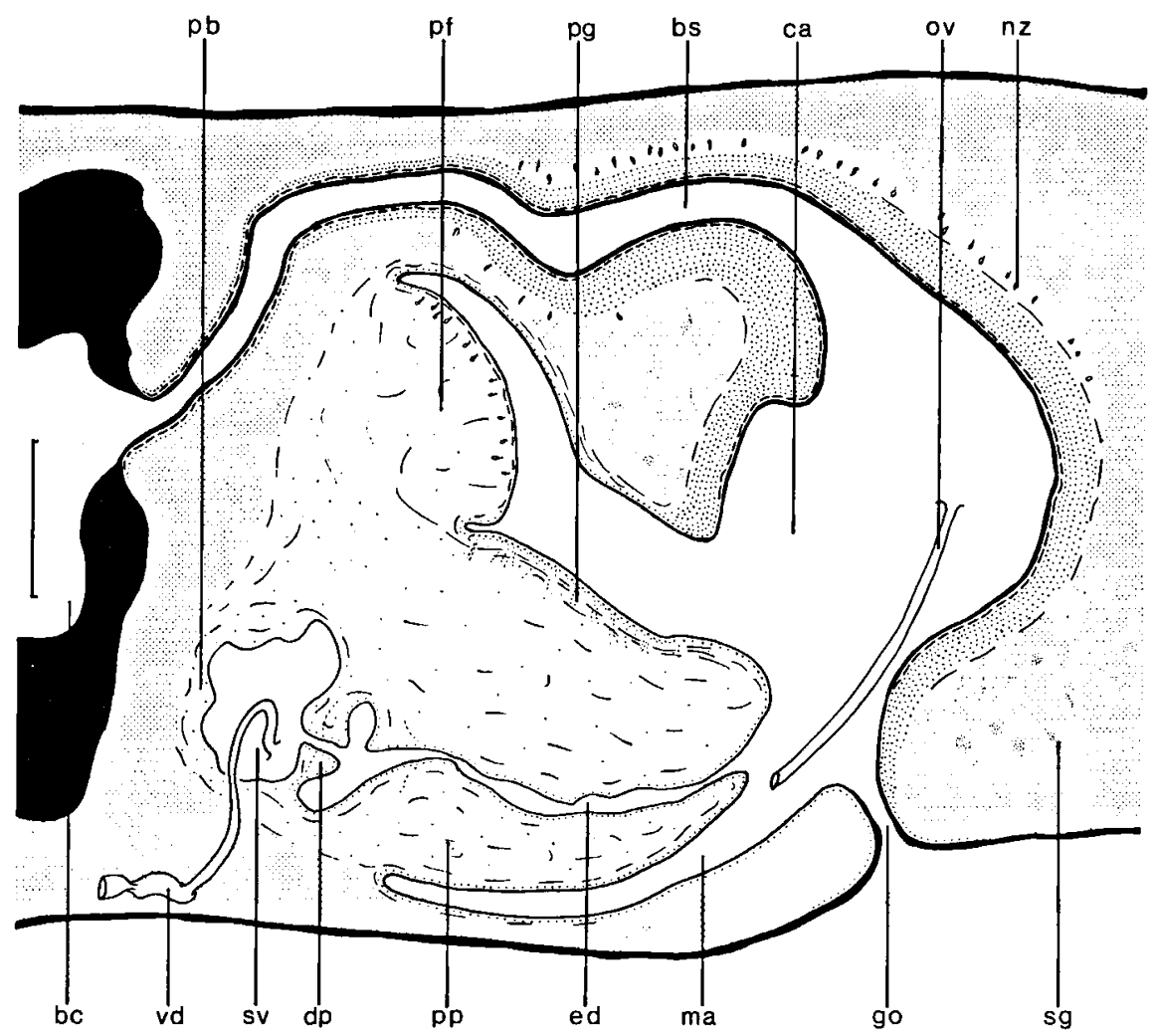

Fig. 4. Dugesia malickyi sp. nov., diagrammatic sagittal reconstruction of the copulatory apparatus (ZMA V.Pl.635.1).



Fig. 5. Dugesia damoae sp. nov., diagrammatic sagittal reconstruction of the copulatory apparatus (ZMA V.Pl.630.1). 
The ventral ejaculatory duct is also unusual within the group.

Dugesia damoae sp. nov.

(Figs. 5, 6 \& 9C-D)

Type-material. - Stream near Manolates, Samos, Greece, $37^{\circ} 47^{\prime} \mathrm{N} 26^{\circ} 49^{\prime}$ E. Coll. H. Malicky, 27-29 May 1979 (Samos 8). Holotype: sagittal sections on five slides (ZMA V.Pl.630.1). Paratypes: one whole mount (ZMA V.Pl.630.2), two sets of sagittal sections (ZMA V.P1.630.6-7), two sets of frontal sections (ZMA V.P1.630.4 630.8), one set of transverse sections (ZMA V.PI.630.5), specimens in alcohol (ZMA V.Pl.630).

Etymology. - The species is named after the philosopher Damo from Samos, daughter of Pythagoras and Theano.

Description. - The animals are rather large, their length in preserved condition measuring up to $10 \mathrm{~mm}$ and their width up to $3 \mathrm{~mm}$.

The ovaries are normal in size and shape and they are positioned ventrally between the third and fifth branch of the intestines.

The testes begin in front of the ovaries. The vasa deferentia form large false seminal vesicles, before entering the penis bulb where they open into the seminal vesicle.

The bursa copulatrix is enveloped by a thin but distinct layer of oblique muscles. In some specimens a spermatophore is present in the bursa. The bursal canal runs slightly to the left of the copulatory apparatus and opens rather posteriorly into the atrium, thereby dividing the atrium into a male and a common atrium. The lumen of the bursal canal is lined with an infranucleate epithelium; in not fully mature specimens however, the epithelium is nucleate. The musculature of the vaginal area is well developed and an ectal reinforcement is present and extends about halfway to the bursa.

The penis bulb is formed by a distinct but thin muscle layer enveloping the seminal vesicle. The conical penis papilla is large and muscular. The ejaculatory duct runs centrally through the papilla, opens at its tip and is in places surrounded by glands. A valve-like, glandular diaphragm separates the ejaculatory duct from the seminal vesicle. An adenodactyl

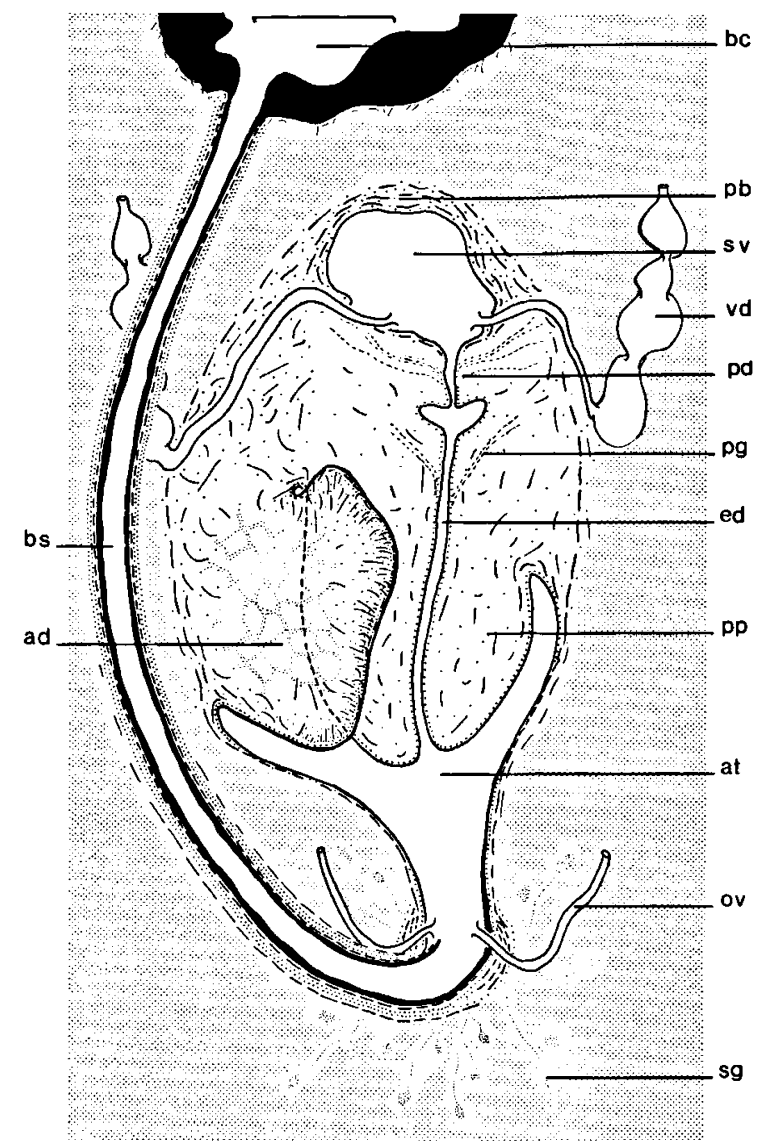

Fig. 6. Dugesia damoae sp. nov., diagrammatic frontal reconstruction of the copulatory apparatus (ZMA V.P1.630.3). Bursal canal drawn slightly to the left for reasons of clarity.

is suspended on the dorsal atrial wall, extending laterally to the left of the papilla and consisting of parenchymatic tissue with some sparse glands, surrounded by a sheet of longitudinal and circular muscles. The musculature of the penis bulb reaches to the dorsal side of the adenodactyl. The whole aspect of the copulatory apparatus is one of great muscularity.

Dugesia ariadnae sp. nov.

(Figs. 7, 8 \& 9E-F)

Type-material. - Stream northeast of Koronis, Naxos, Greece, $37^{\circ} 09^{\prime} \mathrm{N} 25^{\circ} 33^{\prime}$ E. Coll. H. Malicky, 21 May 1976 (Naxos 5). Holotype: sagittal sections on three slides (ZMA V.Pl.628.1). Paratypes: one whole mount 


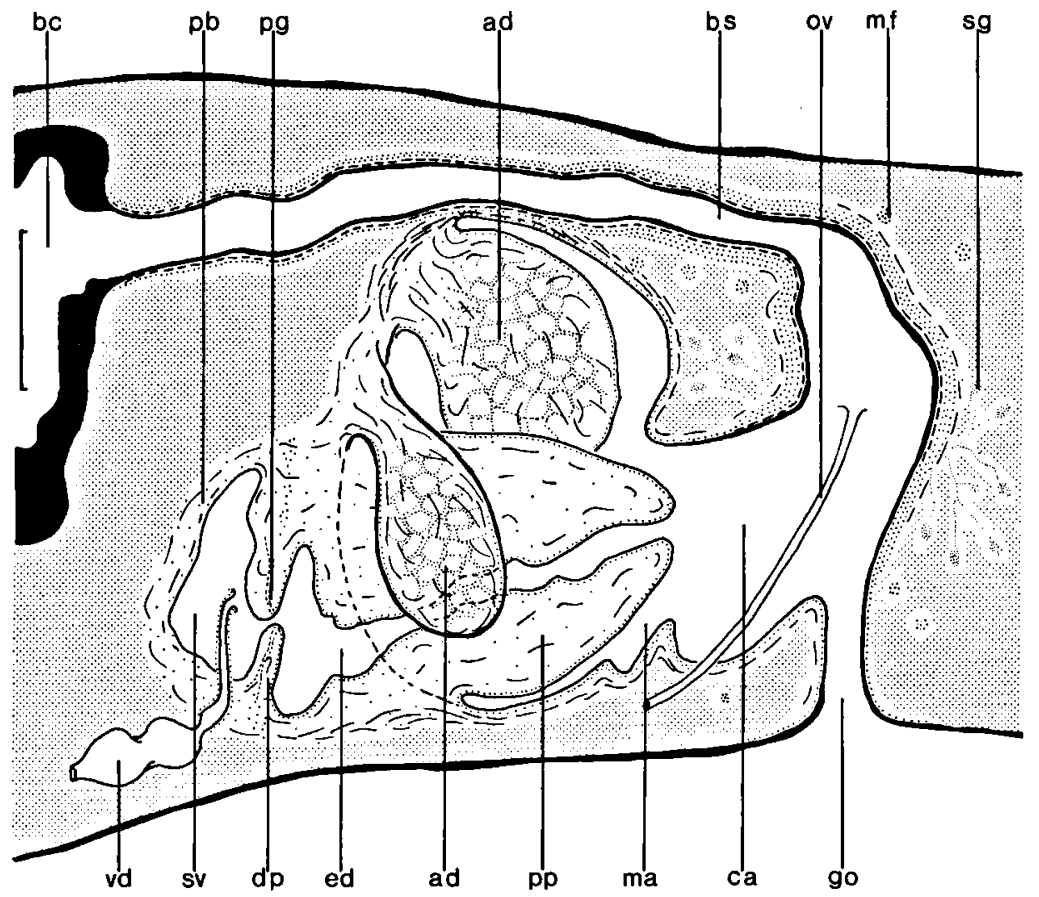

Fig. 7. Dugesia ariadnae sp. nov., diagrammatic sagittal reconstruction of the copulatory apparatus (ZMA V.P1.628.1).

(ZMA V.Pl.628.4), two sets of sagittal sections (ZMA V.Pl.628.5-6), one set of frontal sections (ZMA V.Pl.628.2), one set of transverse sections (ZMA V.P1.628.3).

Other material. - Stream above Koronis, Naxos, Greece, $37^{\circ} 08^{\prime} \mathrm{N} 25^{\circ} 32^{\prime} \mathrm{E}$. Coll. H. Malicky, 26-28 October 1980 (Naxos 26). One set of sagittal sections (ZMA V.Pl.629.1), one set of frontal sections (ZMA V.Pl.629.2), alcohol specimens (ZMA V.Pl.629).

Etymology. - Named after the mythological figure of Ariadna, daughter of king Minos from Crete, who was left behind by Theseus on the isle of Naxos after having helped him kill the Minotaur.

Description. - The preserved specimens reach a length of $8 \mathrm{~mm}$ and a width of $2 \mathrm{~mm}$.

The ovaries are normal in size and shape and situated ventrally between the fourth and fifth intestinal branch.

The testes begin at the level of the ovaries. The vasa deferentia form large extra-bulbar seminal vesicles before entering the penis bulb where they open into the seminal vesicle.
The bursal canal runs from the bursa to the atrium, being situated slightly to the left of the penis, and the lumen is lined with an infranucleate epithelium in mature animals; in not fully mature animals it is nucleate. The inner longitudinal muscle layer of the bursal canal is very distinct. An ectal reinforcement is present, which extends about halfway to the bursa.

The penis bulb consists of a thin but distinct layer of muscles enveloping the spacious and folded seminal vesicle. The seminal vesicle is separated from the ejaculatory duct in the penis papilla by a distinct valve-like diaphragm. The ejaculatory duct runs centrally through the rounded conical penis papilla and it is in places very dilated, especially directly behind the diaphragm. There are some penial glands in the diaphragm and surrounding the ejaculatory duct. The penis papilla protrudes somewhat obliquely into the atrium. Two adenodactyls, one at each side of the penis, are suspended from the dorsal atrial wall close to the base of the penis papilla. Both adenodactyls consist of 


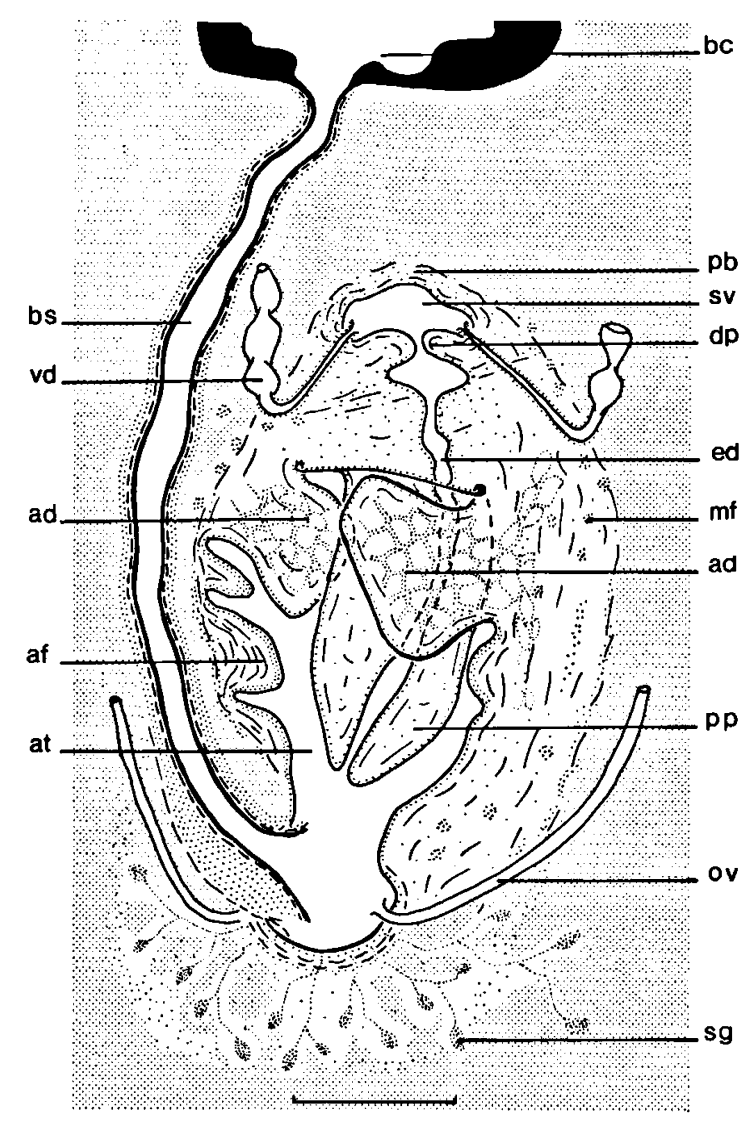

Fig. 8. Dugesia ariadnae sp. nov., diagrammatic frontal reconstruction of the copulatory apparatus (ZMA V.Pl.628.2). Bursal canal drawn slightly to the left for reasons of clarity.

parenchymatic tissue with some scattered glands, surrounded by a muscular sheet.

The parenchymatic tissue of the adenodactyls may penetrate into the surrounding tissue. The atrium is rather wide so that it can contain all these structures. The atrial wall is folded and muscular. Some of these atrial folds divide the atrium into a male and a common atrium. Bundles of muscle fibres are present in the tissue surrounding the atrium.

Remarks. - The morphology of the copulatory apparatus is complicated, which is in part caused by the presence of two adenodactyls, but also by the asymmetrical setting of the penis papilla in the atrium, all of which make it difficult to interpret the serial sections.
Dugesia aenigma sp. nov.

(Figs. $10 \& 13 \mathrm{~A}-\mathrm{B}$ )

Planaria sagitta Schmidt, 1861: 14 (in part; Cephalonia material).

Type-material. - Stream north of Charaktion, Cephalonia, Greece, $38^{\circ} 10^{\prime} \mathrm{N} 20^{\circ} 41^{\prime} \mathrm{E}$. Coll. $\mathrm{H}$. Malicky, 1 June 1977 (Kef. 2). Holotype: sagittal sections on 3 slides (ZMA V.Pl.642.1). Paratypes: one whole mount (ZMA V.Pl.624.7), four sets of sagittal sections (ZMA V.Pl.642.2-5), one set of horizontal sections on 3 slides (ZMA V.Pl.624.6), specimens in alcohol (ZMA V.Pl.624).

Other material. - Kulurata, Cephalonia, Greece, $38^{\circ} 12^{\prime} \mathrm{N} 20^{\circ} 40^{\prime} \mathrm{E}$. Coll. H. Malicky, 31 May 1977 and 27-28 September 1980 (Kef. 1). Five sets of sagittal sections (ZMA V.Pl.643.1-5), specimens in alcohol (ZMA V.Pl.643).

Pastra, Cephalonia, Greece, $35^{\circ} 05^{\prime} \mathrm{N} 20^{\circ} 45^{\prime} \mathrm{E}$. Coll. H. Malicky, 27 September 1980 (Kef. 25). Two sets of sagittal sections of not fully mature specimens (ZMA V.Pl.644.1-2), specimens in alcohol (ZMA V.Pl.644).

Agrostoli, Cephalonia, Greece. Coll. J. Wilhelmi, June 1908. One set of sagittal sections (ZMB 5384), specimens in alcohol (ZMB 5384).

Etymology. - Dedicated to a friend pictured within.

Description. - Preserved specimens reach a length of $8 \mathrm{~mm}$ and a width of $2 \mathrm{~mm}$.

The ovaries are large but normal and positioned between the fifth and sixth intestinal branch.

The testes begin in front of the ovaries. The vasa deferentia form small extra-bulbar seminal vesicles before entering the penis bulb where they open into the seminal vesicle close to the diaphragm.

The bursa copulatrix is large and often contains a spermatophore, the bursal canal runs almost medially over the copulatory apparatus. In the majority of the specimens the bursal canal is lined with an infranucleate epithelium, although in some specimens this epithelium is nucleate. In the vaginal area some ectal reinforcement can be seen in the vaginal area. The atrium is divided into a male and a common atrium.

The penis bulb consists of a thin layer of muscles surrounding the spacious and lobed 

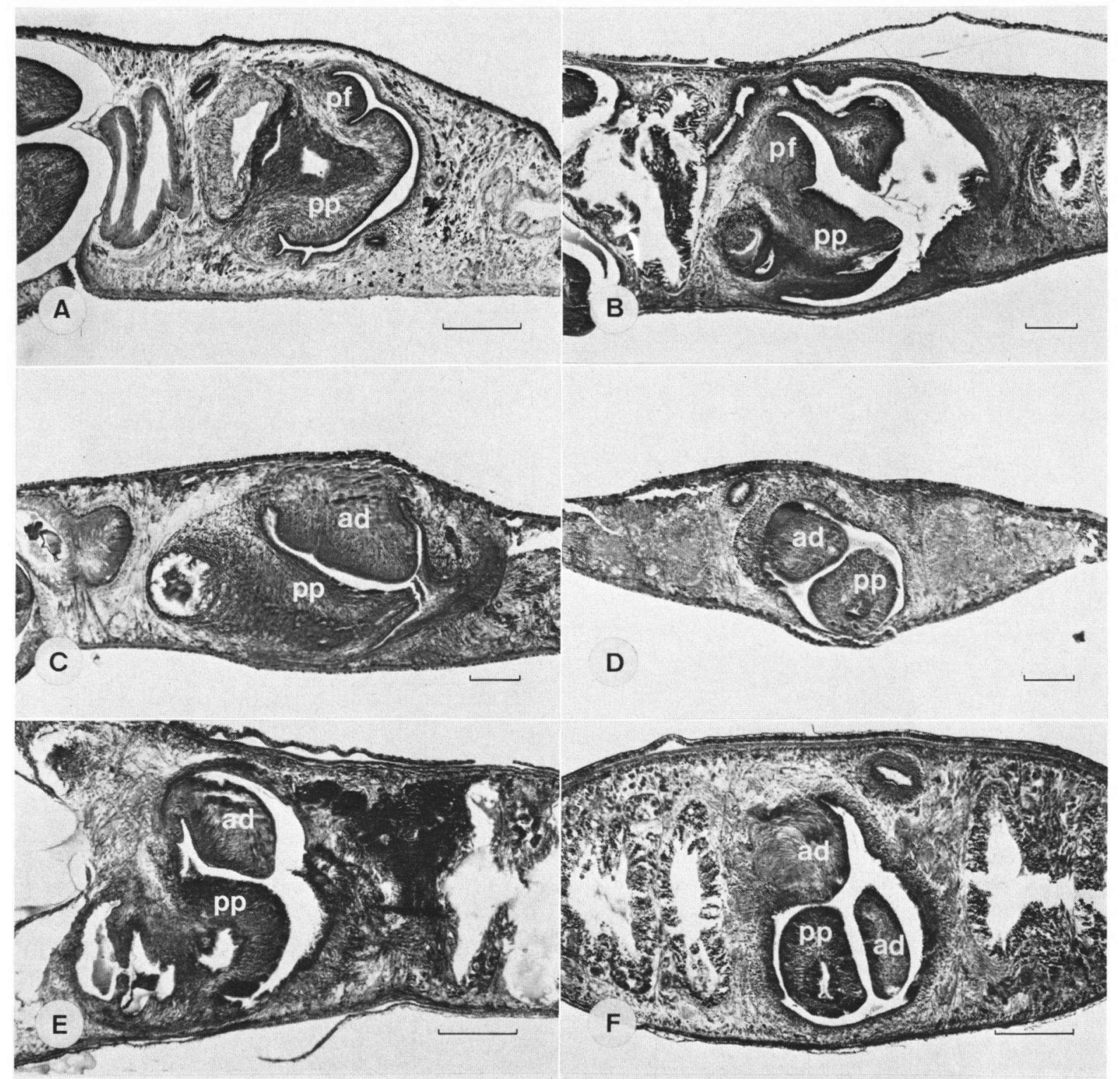

Fig. 9. Microphotographs of sections through the copulatory apparatus of: A, Dugesia sagitta (Schmidt, 1861), sagittal section viewed from the left side (ZMA V.P1.624.1). B, Dugesia malickyi sp. nov., sagittal section viewed from the left side (ZMA V.Pl.635.1). C, Dugesia damoae sp. nov., sagittal section viewed from the left side (ZMA V.P1.630.1). D, Dugesia damoae sp. nov., transverse section viewed from anterior to posterior (ZMA V.Pl.630.5). E, Dugesia ariadnae sp. nov., sagittal section viewed from the left side (ZMA V.Pl.628.1). F, Dugesia ariadnae sp. nov., transverse section viewed from posterior to anterior (ZMA V.PI.628.3). All scale bars indicate $200 \mu \mathrm{m}$.

seminal vesicle. The penis papilla hangs down in the atrium and is short, blunt and plugshaped, and invaginations in the tip of the penis papilla are often to be seen. The ejaculatory duct which is in places dilated, runs centrally through the papilla and has a terminal opening.
The diaphragm is valve-like, there are excessive penial glands in the diaphragm and the papilla, but they do not form such a distinct glandular zone as in $D$. sagitta. The dorsal side of the papilla is very glandular.

The morphology of the copulatory apparatus 


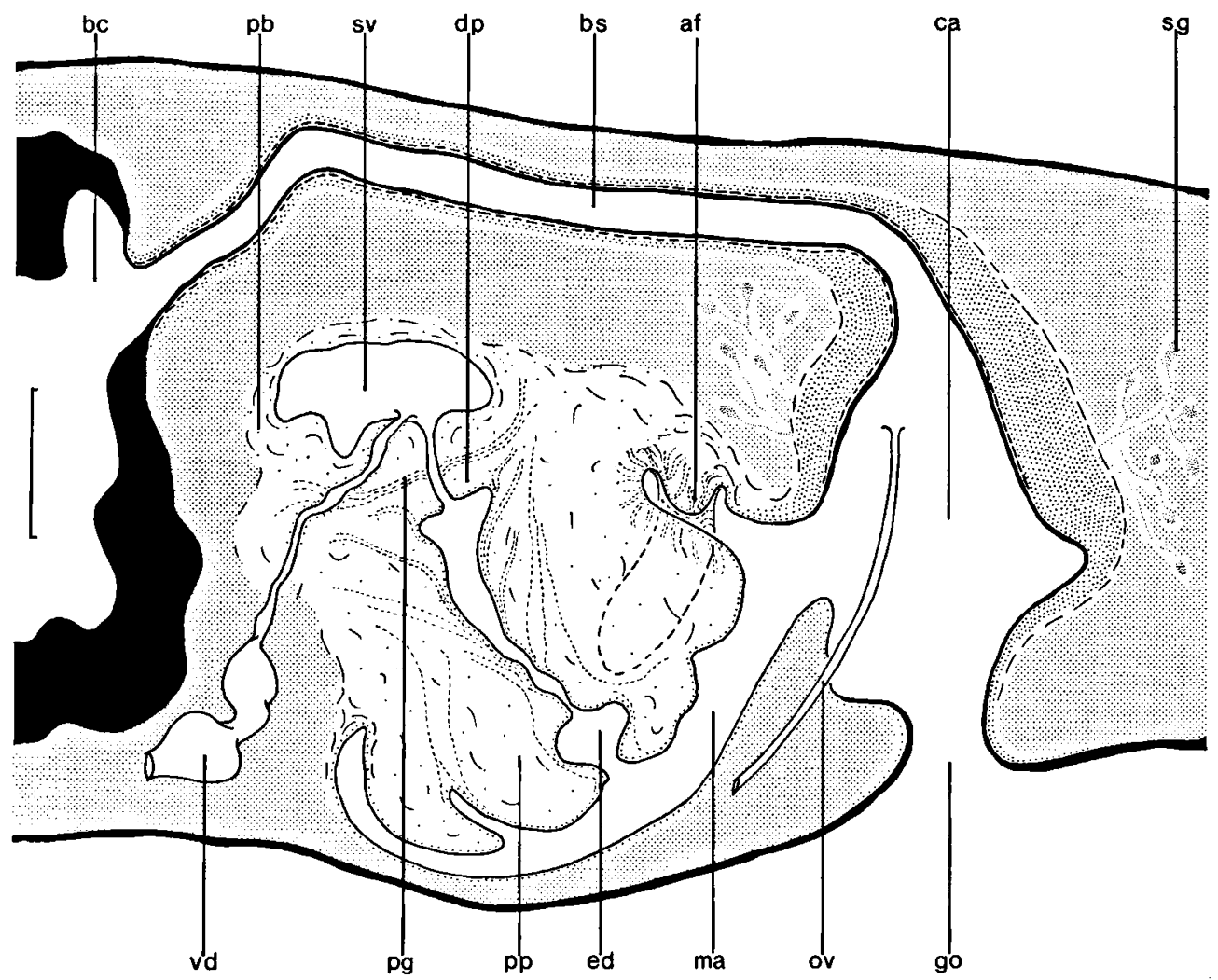

Fig. 10. Dugesia aenigma sp. nov., diagrammatic sagittal reconstruction (ZMA V.P1.642.1).

is complex because of the structure of the atrial wall. Close to the base of the papilla and beginning at the lateral median level, there is a muscular and glandular ridge-like fold in the atrial wall which protrudes into the atrium. The appearance of this fold varies considerably, even between specimens belonging to the same population. In most specimens the fold runs along the left atrial wall dorsally over the penis papilla to the right atrial wall, but it does not extend over the ventral atrial wall. Dorsally of the median axis of the penis papilla it is not so well developed, so that it is not obvious on median sections. In some specimens the fold is only present on one side of the penis, whereas in one other individual the muscular and glandular fold has invaginated into the atrial wall (fig. 13B). Nevertheless, a muscular area in the dorsal side of the atrial wall close to the papilla is always visible, even in not fully mature specimens.
Remarks. - Schmidt (1861) recorded $D$. sagitta from Corfu and Cephalonia, but his identification of the specimens from Cephalonia was only based on external appearance. The present survey suggests that Schmidt was probably dealing with two separate species. The name $D$. sagitta is reserved for the species from the first locality mentioned by Schmidt, viz. Corfu, and the species from Cephalonia has been given a new species name.

Dugesia minotauros sp. nov.

(Figs. 11 \& 13C-D)

Type-material. - Stream about $8 \mathrm{~km}$ south of Rethimnon, Crete, Greece. Coll. J. P. Duffels, 25 May 1982. Holotype: one set of sagittal sections (ZMA V.Pl.636.1). Paratypes: one set of sagittal sections (ZMA V.Pl.636.2), one set of frontal sections (ZMA V.Pl.636.3), one set of transverse sections (ZMA V.Pl.636.4), specimens in alcohol (ZMA V.Pl.636).

Other material. - Stream near Kaminaki, Crete, 
Greece, $35^{\circ} 09^{\prime} \mathrm{N} 25^{\circ} 27^{\prime}$ E. Coll. H. Malicky, 12 May 1971 (K. 71), two sets of sagittal sections (ZMA V.Pl.637.1-2).

Stream near Agios Nicolaos, Crete, Greece, $35^{\circ} 12^{\prime} \mathrm{N}$ $24^{\circ} 28^{\prime}$ E. Coll. H. Malicky, October 1971 (K. 282), one set of sagittal sections (ZMA V.Pl.638.1), specimens in alcohol (ZMA V.Pl.638).

Stream east of Agios Ioannis, Crete, Greece, $35^{\circ} 03^{\prime} \mathrm{N}$ $25^{\circ} 53^{\prime}$ E. Coll. H. Malicky, 8 May 1979 (K. 603), one set of sagittal sections (ZMA V.Pl.639.1), specimens in alcohol (ZMA V.Pl.639).

Stream near Kalamafka, Crete, Greece, $35^{\circ} 04^{\prime} \mathrm{N}$ $25^{\circ} 40^{\prime}$ E. Coll. H. Malicky, 23 September 1972 (K. 217), one set of sagittal sections of immature specimen (ZMA V.P1.640.1), specimens in alcohol (ZMA V.Pl.640).

Stream near Arkadi, Crete, Greece, $35^{\circ} 18^{\prime} \mathrm{N} 24^{\circ} 37^{\prime} \mathrm{E}$. Coll. H. Malicky, 4 October 1972 (K. 268), one set of sagittal sections (ZMA V.Pl.641.1), specimens in alcohol (ZMA V.Pl.641).

Etymology. - Named after the minotaur from Crete, a mythological figure which was half bull, half human.

Description. - The animals are large, in preserved state reaching lengths of about 12 $\mathrm{mm}$, their width reaching up to $3 \mathrm{~mm}$.

The ventral ovaries are very large, the majority of the animals studied possessed hyperplastic ovaries with clusters of small oocytes scattered through the frontal part of the animal. Normally developed oocytes were only rarely found.

The testes are normally developed with many ripe spermatozoa. The vasa deferentia form small extra-bulbar seminal vesicles before entering the penis bulb to open from a dorsal position into the seminal vesicle.

In several specimens a spermatophore was found in the bursa copulatrix. The bursal canal runs to the left of the copulatory apparatus to open into the undivided atrium. In most specimens the lumen of the bursal canal is lined with a nucleate epithelium, but some specimens possess an infranucleate epithelium. The ectal reinforcement is almost completely confined to the vaginal area.

The penis consists of a muscular penis bulb, enclosing a spacious seminal vesicle, and a muscular penis papilla which protrudes somewhat obliquely into the atrium. The

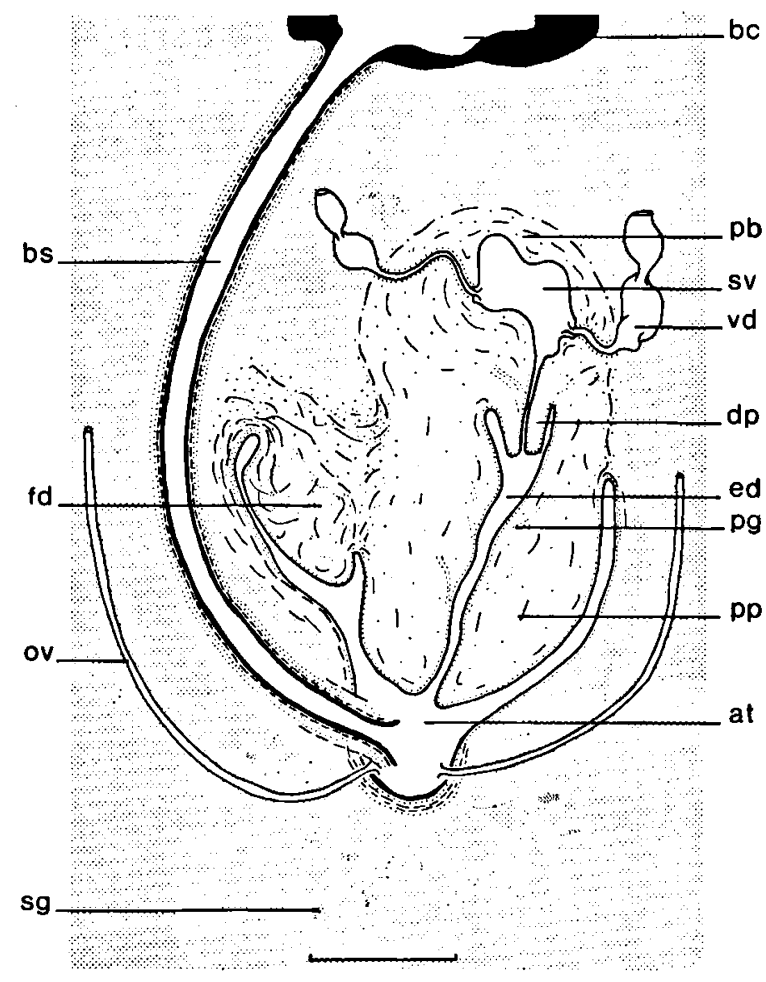

Fig. 11. Dugesia minotauros sp. nov., diagrammatic frontal reconstruction of the copulatory apparatus (ZMA V.Pl.636.3). Bursal canal drawn slightly to the left for reasons of clarity.

diaphragm between the seminal vesicle and the ejaculatory duct is well developed and funnelshaped. The penis papilla is a muscular and elongate cone; the ejaculatory duct is surrounded by many penis glands and runs centrally through the papilla to open terminally.

On the left of the base of the penis papilla, and at a level slightly higher than the seminal vesicle, there is a fold-like protuberance, which is both muscular and glandular. The musculature lining the atrial wall close to the "fold" is more developed than in other parts of the atrial wall. The centre of the "fold" consists of parenchymatic tissue with muscular fibres running through it and in places the parenchymatic tissue from the "fold" penetrates the surrounding tissue.

Remarks. - The hyperplastic ovaries in this species are noteworthy since it is known that in individuals with hyperplastic ovaries, 


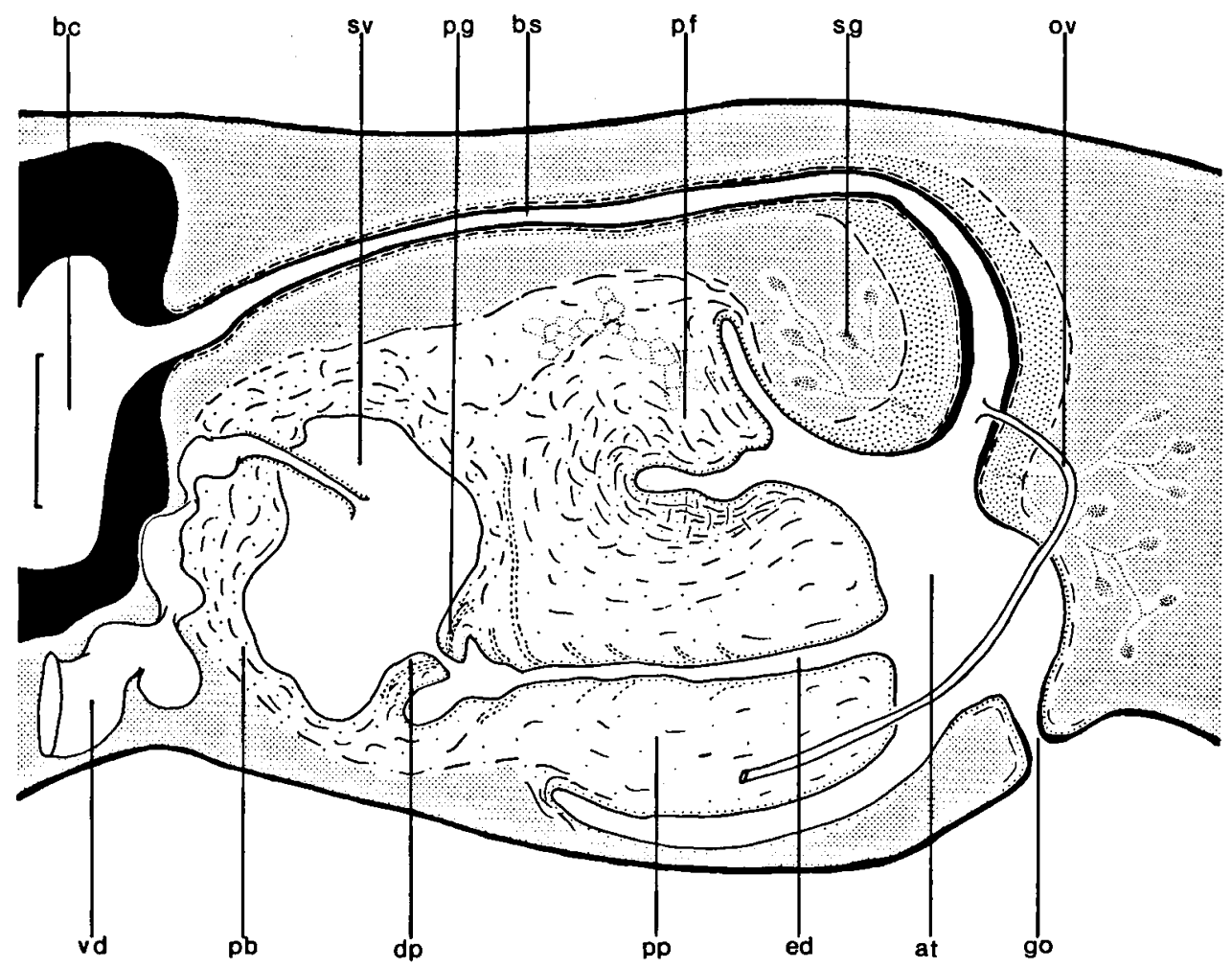

Fig. 12. Dugesia elegans sp. nov., diagrammatic sagittal reconstruction of the copulatory apparatus (ZMA V.Pl.645.1).

polyploidy and aberrant forms of sexual reproduction may occur (Benazzi \& Grasso, 1977; Bromley, 1977). Polyploidy as well as diploidy are recorded for $D$. cretica (cf. section on karyology of $D$. cretica) and there is a distinct possibility that the polyploid individuals investigated (Benazzi \& Benazzi-Lentati, 1976) may have belonged to $D$. minotauros, here newly described.

\section{Dugesia elegans sp. nov.}

(Figs. 12 \& 13E-F)

Type-material. - Stream in the Butterfly Valley near Petaludes, Rhodes, Greece. Coll. E. J. de Vries, 25 May 1982. Holotype: one set of sagittal sections (ZMA V.Pl.645.1). Paratypes: one whole mount (ZMA V.Pl.645.10), four sets of sagittal sections (ZMA V.Pl.645.2-645.5), one set of horizontal sections (ZMA V.Pl.645.9) and two sets of transverse sections (ZMA V.Pl.645.7 8).

Other material. - $2 \mathrm{~km}$ southwest of Laerma, Rhodes, Greece, $36^{\circ} 08^{\prime} \mathrm{N} 27^{\circ} 55^{\prime}$ E. Coll. H. Malicky, 6
May 1975 (R. 5). One set of sagittal sections (ZMA V.Pl.646.1).

Etymology. - The specific epithet is derived from the Latin elegans meaning neat or elegant and refers to the slender and elegant external appearance of the species.

Description. - The animals are sexually mature at very small sizes: animals of $5 \mathrm{~mm}$ length and $1.5 \mathrm{~mm}$ width were already completely sexually developed. Several animals were cultured in the laboratory and they reached a length of up to $10 \mathrm{~mm}$, their width remaining $1.5 \mathrm{~mm}$, giving them a very slender and elegant appearance.

The ovaries are normal and well developed and situated in the area of the fifth intestinal ramus; meiotic phases are to be seen in many specimens. The oviducts leave the ovaries from the posterior lateral side instead of from the dorsal wall, as in the other species. 
The testes begin behind the level of the ovaries. The vasa deferentia form large extrabulbar seminal vesicles, before bending up to enter the penis bulb, where they open into the seminal vesicle.

The bursa is compact and often contains a spermatophore. The bursal canal runs to the left of the copulatory apparatus and opens somewhat laterally into the undivided atrium. The lumen of the bursal canal is in most animals lined with an infranucleate epithelium, although in other specimens a nucleate epithelium is observed too. In the vaginal area the bursal musculature is very well developed and some fibres of ectal reinforcement are present which are mostly confined to the vaginal area.

The penis bulb is formed by a well-developed muscle layer surrounding the spacious seminal vesicle. The penis papilla is blunt and muscular and protrudes obliquely into the atrium, so that the whole length of the ejaculatory duct is not seen in medial sagittal sections. The ejaculatory duct is central with a terminal opening. The diaphragm is funnel-shaped. Dorsal to the penis and somewhat to the left of it is a blunt, muscular projection into the atrium. The bulk of this projection is formed by muscles and some glands, but parenchymatic tissue can be seen too, which in places penetrates into the surrounding tissue. The muscles of the dorsal "fold"' extend into the dorsal side of the papilla, here giving the dorsal part of the papilla a more muscular aspect than the ventral part. There are penial glands surrounding the diaphragm and the ejaculatory duct.

Karyology. - Material of $D$. elegans from the type-locality has been analysed karyologically and all the specimens studied proved to be sexual diploids, $2 n=2 x=16$, all of the chromosomes being metacentric.

Remarks. - Although some characters are shared between $D$. malickyi and $D$. elegans, the two species can be distinguished by the muscularity and the shape of the penis papilla in the latter species, whereas in $D$. malickyi the penis is only weakly muscular and has its ejaculatory duct ventrally. Furthermore, the body sizes of the two species differ significantly, D. elegans being much smaller and thinner than D. malickyi.

\section{DISCUSSION}

The wealth of morphological data obtained here from the Greek species makes possible some general statements on the taxonomic validity of several morphological characteristics from the $D$. gonocephala group as a whole and from the Mediterranean representatives in particular. As a consequence of our increasing knowledge of D. gonocephala s.l. it is clear that the validity of several features, traditionally thought to be of taxonomic importance, is questionable.

\section{Pharyngeal musculature}

A morphological feature which was commonly believed to be of taxonomic value is the extra longitudinal muscle layer in the outer pharyngeal muscle zone. Kenk (1930a), for example, laid stress on this feature for distinguishing immature specimens of $D$. cretica from $D$. gonocephala and he thought that it might prove a good defining character for the latter species. Other authors frequently have referred to the discriminatory value of this character even, as in some cases, when the collections under study were entirely asexual (e.g. Marcus, 1953, 1955; Dahm, 1967; Ball, 1970; Young \& Young, 1974). On the other hand, De Beauchamp (1936) has always stressed the variability, and hence unreliability, of this character, even within the single "species" $D$. gonocephala.

The evidence now favours De Beauchamp's opinion. In their characterization of $D$. gonocephala s. str., De Vries \& Ball (1980) noted that, whereas this third muscle layer was usually present in the species, it could not always be demonstrated in every individual of a population; in some individuals, moreover, it was so diffuse as to be demonstrable in only some of the sections. The statement by these authors 




Fig. 13. Microphotographs of sections through the copulatory apparatus of: A, Dugesia aenigma sp. nov., sagittal section viewed from the left side (ZMA V.Pl.642.1). B, Dugesia aenigma sp. nov., sagittal section viewed from the left side (ZMA V.Pl.642.4). C, Dugesia minotauros sp. nov., frontal sections viewed from dorsal to ventral (ZMA V.Pl.636.3). D, Dugesia minotauros sp. nov., sagittal section viewed from the left side (ZMA V.Pl.636.1). E, Dugesia elegans sp. nov., sagittal section viewed from the left side (ZMA V.P1.645.1). F, Dugesia elegans sp. nov., transverse section viewed from posterior to anterior (ZMA V.Pl.645.10). All scale bars indicate $200 \mu \mathrm{m}$.

that this layer is absent in the species as known from Corfu may now be ignored since these specimens are herein referred to $D$. sagitta (Schmidt). Several members of the $D$. gonocephala group from Africa are now known to possess this character (Dahm, 1971) and it has been recorded from some populations of $D$. japonica (see Kawakatsu et al., 1976). A distinct extra longitudinal layer has also been found in two populations of $D$. iberica Gourbault \& Benazzi, 1979, from Mallorca (coll. H. Malicky) although it was not recorded in the 
TABLE I

Distribution of character states within the Greek species of the Dugesia gonocephala group.

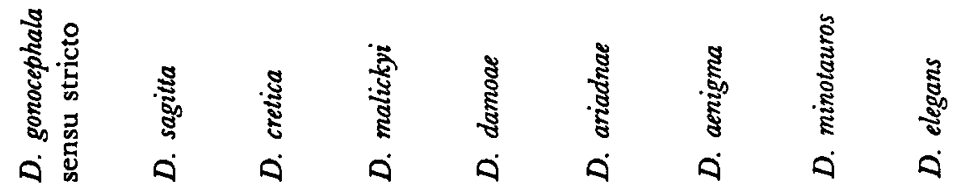

\section{Character}

Oviducts arise from ovaries:

- dorsally

- laterally

Bursal canal epithelium:

- nucleate

- infranucleate

Atrium:

- divided

- undivided

Penis bulb:

- very muscular

- muscular

- weakly developed

Shape of penis papilla:

- conical

- rounded conical

- elongate conical

- plug shaped

- blunt

Shape of penis diaphragm:

- funnel

- valve

Adenodactyl:

Fold:

- atrial

- penial

$\begin{array}{lllllllll}+ & + & + & + & + & + & + & + & - \\ + & - & - & - & - & - & - & - & + \\ + & + & - & - & + & + & + & + & + \\ + & - & + & + & + & + & + & - & - \\ - & + & - & - & - & - & - & + & + \\ + & - & - & - & - & - & - & - & - \\ - & - & + & - & + & + & - & + & + \\ - & + & - & + & - & - & + & - & - \\ - & - & + & + & + & - & - & - & - \\ - & + & - & - & - & + & - & - & - \\ + & - & - & - & - & - & - & + & - \\ - & - & - & - & - & - & + & - & - \\ - & - & - & - & - & - & - & - & + \\ + & - & + & - & - & - & - & + & + \\ - & + & - & + & + & + & + & - & - \\ - & - & + & - & + & + & - & - & - \\ + & + & - & ? & - & - & + & ? & ? \\ + & - & ? & - & - & - & ? & ?\end{array}$

original description of other populations from Mallorca (Gourbault \& Benazzi, 1979).

Evidently the classificatory significance of this character now needs re-assessment. It may be stated however, that in so far as the Mediterranean species are concerned the extra layer of longitudinal muscles in the outer muscle zone of the pharynx is absent with the exception of some populations of $D$. iberica from Mallorca and possibly some individuals of $D$. ariadnae (from Naxos); in the latter case some scattered fibres were to be seen in only one individual.

\section{Epithelium of the bursal canal}

The taxonomic importance of the nucleation of the epithelium lining the bursal canal has also been the subject of much discussion. Marcus (1953) suspected that this character might be variable, which is confirmed by the findings of De Vries \& Ball (1980) in populations of $D$. gonocephala s. str. from western Europe. The data derived here from the Greek species show unequivocally that the nucleation of the epithelium depends, as would be expected, on 
the state of development of the copulatory apparatus. D. malickyi and $D$. cretica consistently possessed a nucleate epithelium, whilst in $D$. sagitta only an infranucleate epithelium was present, but in all the other species the type of epithelium depended upon the state of maturity: while in fully mature specimens the epithelium of the bursal canal was infranucleate, in less mature specimens it was nucleate. Intermediate situations were observed in some cases wherein the epithelium of the vaginal region was infranucleate whereas closer to the bursa itself it was nucleate.

It follows from these observations that the state of nucleation of the epithelium of the bursal canal is of taxonomic significance only when assessed on fully mature individuals.

\section{Adenodactyls and similar structures}

Probably the most difficult morphological features to interpret are the structures which are present in the atrium together with the penis papilla. Often it is uncertain whether the accompanying structure is an adenodactyl, a penial fold or an atrial fold.

Adenodactyls are highly differentiated musculoglandular organs of uncertain function, though generally it is assumed that they have a stimulatory function during copulation. A classic discussion of such organs has been given by Kenk (1930b). He recognized three distinct types, the hollow Planaria torva type, the solid Polycelis tenuis type, and a complex hollow Dendrocoelum lacteum type. The details of these need not concern us here because for the most part the "adenodactyls" found in some species of the $D$. gonocephala group do not conform with his classification. Adenodactyls with a lumen, such as are found in $D$. bactriana De Beauchamp, 1959, from Afghanistan, and D. cretica (cf. Kenk, 1930a) are exceptional within the $D$. gonocephala group. For the most part the "adenodactyls" of the Mediterranean species appear to be folds or protuberances of varied size, shape, position and structure, and the terminology of these structures has become confused.
The nature and origin of these "folds" is often unclear, especially if they are situated close to the base of the penis papilla. In principle such questions could be resolved by studying the morphological development of the copulatory apparatus during maturation. If the "fold" is present before the penis papilla has developed, it is most likely to be a direct derivative of the atrial wall rather than a penial fold (Ball, 1970). Unfortunately, however, enough developmental stages are not always available in existing collections, thereby precluding developmental studies. In such cases the morphological and histological structure of the "fold" must be compared with that of the atrial wall and penis papilla, but even so in many cases a reliable conclusion cannot be drawn.

In two of the species described here, D. ariadnae and $D$. damoae, the structures are highly differentiated so that it seems justified to classify them as adenodactyls. $D$. ariadnae is easily identified by its two adenodactyls. $D$. damoae possesses one large adenodactyl, like $D$. etrusca monoadenodactyla Lepori, 1947, but this species differs from $D$. damoae in that the adenodactyl arises from the ventral side of the penial base, instead of from the dorsal atrial wall, as in $D$. damoae.

In $D$. sagitta, the histology and position of the fold clearly proves it to be a penial fold. In $D$. aenigma, the fold is obviously an atrial fold as it is situated quite independently of the base of the penis. In $D$. minotauros, $D$. malickyi and $D$. elegans however, "folds"' are present that cannot unambiguously be classified. The muscular protrusion laterally to the left of the penis papilla in $D$. minotauros could equally be a direct derivative of the atrial wall or of the penis papilla, since the whole area is rather muscular. The structure of the "fold" resembles the one described for D. ilvana Lepori, 1948, from Elba, except that in the latter species the two "adenodactyls" are found laterally on both sides of the penis papilla, whereas in $D$. minotauros the single "fold" is confined to the left side of the penis papilla. In $D$. malickyi and $D$. elegans there is a fold dorsal to the penis. In 
D. malickyi the tissue of the "fold" is more like that of the penis papilla than that of the atrium. In D. elegans the dorsal "fold" consists of a muscular area, from which the muscles extend into the dorsal side of the penis papilla, so that it is closely connected with, and almost a part of, the latter. Developmental studies are necessary for a final elucidation of the nature of the "folds", or adenodactyls, in these three species.

Apart from the species already mentioned there are two other Mediterranean species described as having "adenodactyls": $D$. etrusca Benazzi, 1944, from northern Italy, has two large parenchymatic adenodactyls, one dorsal and one ventral, to the penis papilla, and $D$. benazzii Lepori, 1951, from the Tyrrhenian Islands, has a muscular adenodactyl, the position of which varies (De Beauchamp, 1953).

In some classificatory schemes the numbers and positions of the "adenodactyls" have played an important role (Lepori, 1951; Dahm, 1958). But as has been demonstrated above, the interpretation of these structures is hazardous without developmental studies.

\section{Morphology of the atrium}

The anatomy of the genital atrium, insofar as it may be considered undivided or divided into a male and a common part, has also assumed some taxonomic importance in past studies of the D. gonocephala group (Lepori, 1951; Dahm, 1958). However, in dealing with this characteristic within this group, one has to take into account that the division of the atrium is not as distinct as it is found to be in other genera, such as Polycelis (cf. Ball \& Reynoldson, 1981: figs. 19, 20, 21) and Bdellocephala (Von Graff, 1912-1917).

It is true that there are species of the gonocephala group in which a divided atrium is unambiguously present, as in $D$. gonocephala s. str., where an annular muscular ridge in the atrial wall divides the atrium (De Vries \& Ball, 1980). Yet the criteria by which this feature may be ascertained have never been well defined for the members of the group.
After having studied an extensive number of specimens of the Mediterranean $D$. gonocephala s.l., it can be concluded that the shape of the atrium is greatly influenced by the state of relaxation or contraction of the penis papilla, by the curvature of the fixed animals and even by the fixative used. Consequently, it is obvious that the division of the atrium into a male and a common atrium is arbitrary in many species.

In the present paper the following criteria concerning the atrial morphology are used: if the bursal canal opens high in the roof of the atrium, so that the atrium is one united cavity, opening directly via the gonopore, as in $D$. sagitta, D. minotauros and $D$. elegans, it is called undivided. If the bursal canal runs to a position very posterior of the atrium, opening more or less independently of the atrium into the gonopore, as in $D$. cretica, $D$. damoae, $D$. malickyi and $D$. aenigma, it is classified as divided.

In $D$. ariadnae the morphology of the copulatory apparatus is more complex. In this species the atrial wall forms muscular folds which in one place form a division of the atrium. The appearance of the division depends on the contraction of the muscles and can therefore vary between specimens.

During the present survey, comparative material of other Mediterranean species has been studied, among others several specimens of $D$. etrusca monoadenodactyla. According to the criteria given here, the atrium of this species is to be regarded as divided, although Lepori (1947) describes it as being undivided. This feature needs re-assessment throughout the entire $D$. gonocephala group and its validity as a taxonomic character needs further discussion.

\section{The penis}

In contrast to the morphological features of doubtful diagnostic value, as discussed above, the anatomy of the penis provides several characters which do not vary much within the species and are therefore of taxonomic validity. Even though the shape of the penis is inevitably influenced by its state of contraction and relaxation, it is possible to recognize form differences 
between the species. Thus, the penis papillae of the Greek species may be classified into five categories as shown in table $\mathrm{I}$.

The position of the ejaculatory duct is equally a valid character since it does not seem to vary within the species. In $D$. malickyi the ejaculatory duct runs somewhat ventrally through the papilla, whereas in all other species it follows a central course. The duct opens terminally in all species.

The musculature of the penis bulb is here found to be a consistent feature within the species, though between species it shows a wide range of conditions within the $D$. gonocephala group. This range extends from the welldeveloped, muscular penis bulb as found in $D$. gonocephala s. str. and D. benazzii (Lepori, 1951), to the extremely weakly developed penis bulbs of $D$. sagitta and $D$. malickyi. In between there are different degrees of development of the musculature, ranging from a thin but compact muscle layer surrounding the seminal vesicle as in $D$. damoae, to the more scattered muscles of the penis bulb of $D$. ariadnae and D. aenigma. Of the Greek species described here the penis bulb of $D$. elegans is the most strongly developed.

According to Ball (1974a) the diaphragm separating the seminal vesicle from the ejaculatory duct is an evolutionarily derived, or apomorph, character shared by all the species of the gonocephala group, which he equates with the subgenus Dugesia. A diaphragm is unrecorded in only two oriental species assumed to belong to the subgenus, viz. D. izuensis Kato, 1943 (see Kawakatsu, 1983) and D. annandalei Kaburaki, 1918 , both species being of uncertain taxonomic status. The shape and size of the diaphragm may vary between species; it can be well developed, large and funnel-shaped, as in $D$. gonocephala s. str. and $D$. benazzii, occasionally extending far into the penis papilla, whereas in most of the Mediterranean species it is less developed and shaped like a valve as, for instance, in $D$. sagitta. In the Asiatic and in the African species, the diaphragm is funnelshaped, though much smaller than in $D$. gonocephala s. str., and much more posteriorly situated in the papilla (Ball, 1970; Dahm, 1971;
Kawakatsu, 1972a, 1972b; Kawakatsu \& Basil, 1975; Kawakatsu et al., 1980). The glandular nature of the diaphragm varies between the species: in $D$. sagitta the diaphragm is extremely glandular, whereas in $D$. gonocephala s. str. the glands in the diaphragm are sparse. On the basis of these data it is most likely that the diaphragm will have important implications for an analysis of phylogenetic relationships within the gonocephala group.

\section{Oviducts}

In all but one of the species here described the oviducts arise from the dorsal ovarial wall. $D$. elegans is the exception and in this species they arise from the lateral posterior wall. The taxonomic value of this finding is not known because usually it is not mentioned in species descriptions. From the comparative anatomical study undertaken during this survey a similar condition, of oviducts arising from the dorsal ovarial wall, is known to occur in $D$. benazzii, $D$ iberica and $D$. gonocephala s. str. Yet again we have a feature which needs re-assessment throughout the entire group.

\section{THE DUGESIA GONOCEPHALA GROUP IN GREECE}

In the eastern Mediterranean, specifically Greece and the Greek islands, the Dugesia gonocephala group is now represented by eight species, but undoubtedly more species remain to be discovered. The type-species of the subgenus, $D$. gonocephala s. str., as defined by De Vries \& Ball (1980) has its major area of distribution in western Europe, but it has been recorded from Bulgaria, hence it may be expected to be discovered in Greece if carefully looked for. The geographic distribution of the Greek $D$. gonocephala species is presented in fig. 14.

Table I gives the distribution of several character states, thought to be of taxonomic importance, in the Greek species of the $D$. gonocephala group.

The geographic distribution, as it is known at 


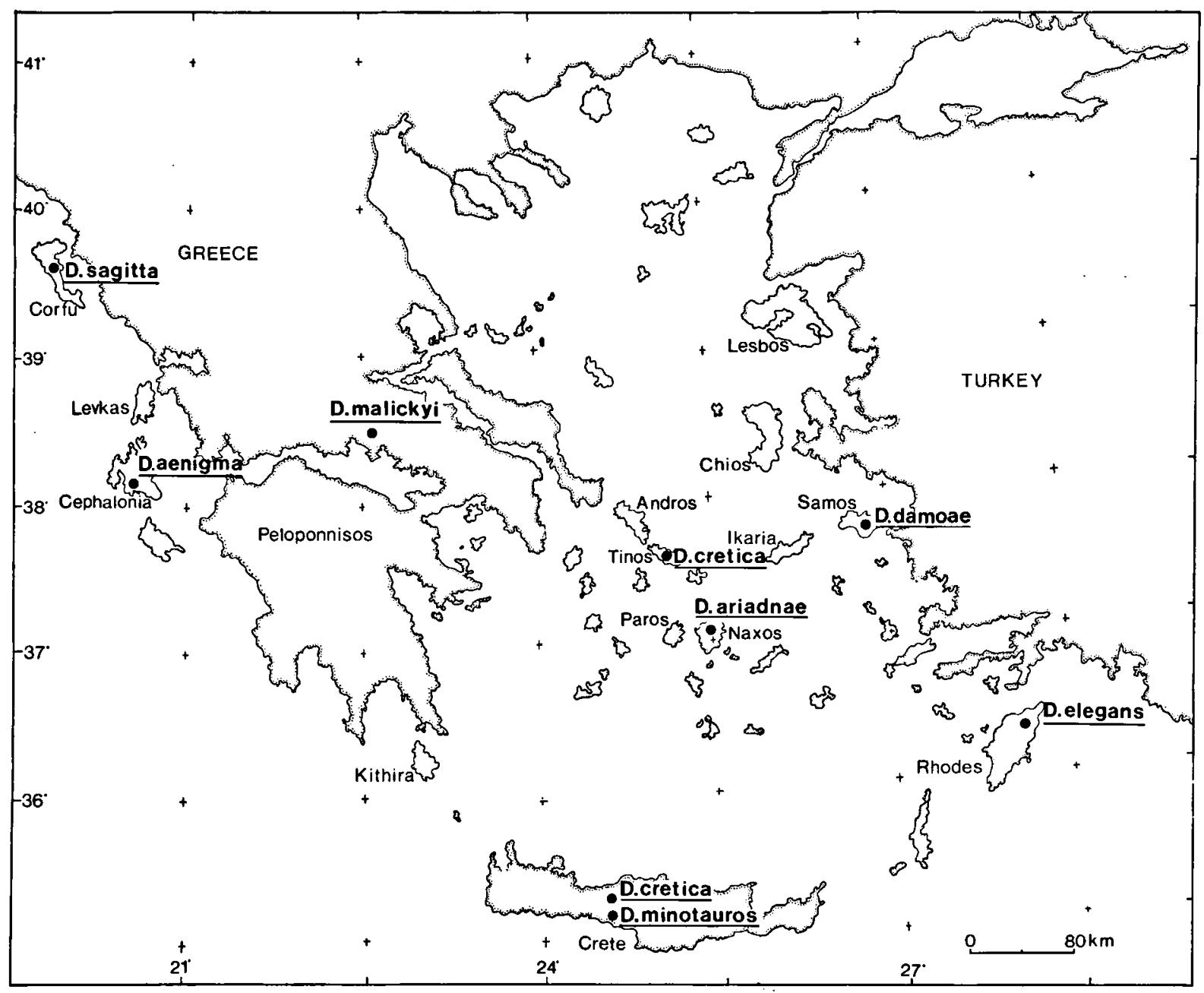

Fig. 14. Geographic distribution of the Greek species of the Dugesia gonocephala group.

present, and the diagnostic characters of the species, are summarized below.

D. gonocephala s. str. (Dugès, 1830)

Mainly distributed throughout western Europe, but also recorded from Bulgaria (De Vries, in prep.). As characterized by De Vries \& Ball (1980), this species may be recognized by its well-developed and elongate conical penis papilla with a large funnel-shaped diaphragm separating the seminal vesicle from the ejaculatory duct, the muscular penis bulb, and by the annular muscular ridge of the atrial wall giving a clearly divided atrium.
D. sagitta (Schmidt, 1861)

Known only from Corfu. This species can be distinguished from the other species of the group by its characteristic glandular zone in the penis, and by the asymmetric fold at the base of the penis. It differs especially from $D$. gonocephala s. str. also in its lack of a true funnelshaped diaphragm, elongate papilla, and annular muscle ridge of the atrial wall.

D. cretica (Meixner, 1928)

This species, as redescribed by Kenk (1930), is known with certainty only from Crete, and also from Tinos (De Vries, in prep.). D. cretica is 
easily identified by its large, muscular adenodactyl situated ventrally from the penis papilla. Typically, this adenodactyl possesses a lumen in the posterior part.

\section{D. malickyi sp. nov.}

Known only from Polydroson, Greece. This species has a large conical penis papilla in which the ejaculatory duct follows a slightly ventral course, a dorsal extension of the penis papilla, and a valve-like diaphragm. The penis bulb and penis papilla are extremely weakly developed, in contrast to the vaginal area, which is very muscular.

D. malickyi shares many characteristics with D. elegans, but differs from it principally in penis shape and muscularity of the copulatory apparatus. Furthermore, D. malickyi reaches significantly larger sizes and has a much plumper body shape than $D$. elegans.

\section{D. damoae sp. nov.}

Recorded only from Samos. This species can be distinguished from the other members of the group by the presence of one dorsal adenodactyl, suspended on the dorsal atrial wall.

\section{D. ariadnae sp. nov.}

Known only from Naxos. This species is characterized by the presence of two adenodactyls suspended on the dorsal atrial wall, one on each side of the penis.

\section{D. aenigma sp. nov.}

Known from Cephalonia. Distinguishable from the other species of the group principally by its plug-shaped penis papilla and a musculoglandular fold which runs from left to right of the penis papilla, along the dorsal atrial wall. The identification of this species may cause difficulties due to the variable appearance of the fold.

\section{D. minotauros sp. nov.}

At present known from Crete. This species can be identified by the following combination of characters: the elongate conical penis papilla, the funnel-shaped diaphragm, and the muscular fold laterally to the left of the penis papilla at a level slightly higher than the seminal vesicle.

\section{D. elegans sp. nov.}

Recorded from Rhodes. Characterized by its muscular penis bulb, the blunt penis papilla and the muscular dorsal penial fold.

This species shares many similarities with $D$. malickyi. The principal differences reside in body size $(D$. elegans is much smaller and slimmer), and the strong muscularity of the penis bulb and dorsal penial fold of this species. (See also D. malickyi.)

\section{ACKNOWLEDGEMENTS}

Dr. Hans Malicky (Biological Station of Lunz, Austria), Prof. Dr. Ian R. Ball (Institute of Taxonomic Zoology, University of Amsterdam) and Dr. J. P. Duffels (ITZ) are thanked for providing the material on which this study is based. The author is grateful to Dr. G. Hartwich of the Museum für Naturkunde in Berlin for his cooperation in Berlin and for the loan of material in his care. I am much indebted to Prof. Ball for his critical comments and helpful discussions and to Dr. P. J. H. van Bree (ITZ) for his collegiality and advice. The photographs were made by $\mathrm{Mr}$. L. van der Laan (ITZ).

\section{REFERENCES}

Ball, I. R., 1970. Freshwater triclads (Turbellaria, Tricladida) from the Oriental region. Zool. J. Linn. Soc., 49: 271-294.

- $1974 \mathrm{a}$. A contribution to the phylogeny and biogeography of the freshwater triclads (Platyhelminthes Turbellaria). In: N. W. Riser \& M. P. Morse eds., Biology of the Turbellaria: 339-401 (McGraw-Hill, New York).

-, $1974 b$. A new genus of freshwater triclads from Tasmania with reviews of the related genera Cura and Neppia (Turbellaria, Tricladida). Life Sci. Contr., R. Ont. Mus., 99: 1-48.

- - 1977. A monograph of the genus Spathula (Platyhelminthes: Turbellaria: Tricladida). Austr. J. Zool., Suppl. Ser., 47: 1-43.

-, 1979 . The karyotypes of two Dugesia species from Corfu, Greece (Platyhelminthes, Turbellaria). Bijdr. Dierk., 48 (2): 187-190.

BALl, I. R. \&. B. Reynoldson, 1981. British planarians (Platyhelminthes, Tricladida). In: Synopses of the British fauna, 19: 1-137 (Cambridge University Press, Cambridge).

Beauchamp, P. DE, 1936. A propos d'Euplanaria cretica Meixner. Bull. Soc. zool. France, 61: 433-440. 
- - 1953. Sur quelques formes de Triclades d'eau douce et leur répartition en Europe. Annls. Stn. cent. Hydrobiol. appl., Fasc. hors Sér.: 178-182.

- , 1959. Triclades paludicoles d'Afghanistan. Kungl. fysiogr. Sällsk. Lund Förh., 29: 27-43.

Benazzi, M., 1944. Nuova specie di planaria trovata nel senes. Atti Accad. Fisiocr. Siena, (II) 12: 19-20.

- , 1955. Evoluzione della poliploidia nelle planarie appartenenti alla superspecie Dugesia gonocephala. Atti Accad. naz. Lincei, (8) 18: 527-533.

-, 1961 . Les planaires des îles Tyrrhéniennes et leur différenciation raciale, cytologique et génétique. In: Le peuplement des îles mediterranéennes et le problème de l'insularité: 103-112 (Ed. CNRS, Paris).

Benazz, M. \& G. Benazzi-Lentati, 1976. Animal cytogenetics, vol. 1, Platyhelminthes: 1-182 (Gebr. Borntraeger, Berlin \& Stuttgart).

Benazzi, M. M. Grasso, 1977. Comparative research on the sexualization of fissiparous planarians treated with substances contained in sexual planarians. Monitore zool. ital., 11: 9-19.

BRomLEY, H., 1974. Morpho-karyological types of Dugesia (Turbellaria, Tricladida) in Israel and their distribution patterns. Zoologica Scr, , 3: 239-242.

- , 1977. Observations on fission, maturation and reproduction in Dugesia biblica (Turbellaria, Tricladida) from Israel. Zoologica. Scr., 6: 197-201.

DAнм, A., 1958. Taxonomy and ecology of five species groups in the family Planariidae: 1-241 (Nya Litografen, Malmö).

- - 1967. A new Dugesia microspecies from Ghana belonging to the Dugesia gonocephala group, Turbellaria, Tricladida, Paludicola. Ark. Zool., 19: 309-321.

-, 1971 . Dugesia sudanica sp. n. from Africa (Turbellaria, Tricladida, Paludicola). Zoologica Scr., 1: 37-41.

Dugès, A., 1830. Aperçu de quelques observations nouvelles sur les Planaires et plusieurs genres voisins. Annls. Sci. nat., 21: 70-91.

Girard, C., 1850. A brief account of the freshwater Planariae of the United States. Proc. Boston Soc. nat. Hist., 3: 264-265.

Gourbault, N. M. Benazzi, 1979. Une nouvelle espèce ibérique du groupe Dugesia gonocephala (Turbellaries, Triclades). Bull. Mus. natn. Hist. nat., Paris, (4) $1 \mathrm{~A}$ (2): 329-337.

GrafF, L. von, 1912-1917. Tricladida. In: H. G. BronN ed., Klassen und Ordnungen des Tier-Reichs, wissenschaftlich dargestellt in Wort und Bild. Vierter Band, Vermes. Abteilung Ic: Turbellaria. II. Abteilung: i-xxxvii, 2601-3369, pls. XXXI-LXIV (C. F. Winter'sche Verlagshandlung, Leipzig).

Hesse, R., 1897. Untersuchungen über die Organe der Lichtempfindung bei niedrigen Thieren, II: Die Augen der Platyhelminthen, insonderheit der tricladen Turbellarien. Z. wiss. Zool., 62: 527-582.
Kaburaki, T., 1918. Freshwater triclads from the basin of the Inlé lake. Rec. Indian Mus., 14: 187-194.

Kato, K., 1943. On freshwater planarians from Japan. Soyokobutu oyobi Dobutu, II: 628-630. [In Japanese.]

Kawakatsu, M., 1972a. Report on the freshwater planarians from South Africa. Bull. Fuji Wom. Coll., 10: $57-79$.

-, $1972 b$. The freshwater planarians from the Phillipines. Annotationes zool. jap., 45: 234-244.

- - 1983. A commentary on the late Dr. K. Kato's 1943 paper in Japanese including the original description of Dugesia izuensis (Turbellaria, Tricladida, Paludicola), with its republication. Occ. Publs. biol. Lab. Fuji Wom. Coll., 9: 1-8.

Kawakatsu, M. J. A. Basil, 1975. The freshwater planarians from South India. Annotationes zool. jap., 48: 34-42.

Kawakatsu, M., I. Oki, S. Tamura \& H. Sugino, 1976. Studies on the morphology, karyology and taxonomy of the japanese freshwater planarian Dugesia japonica Ichikawa \& Kawakatsu, with a description of a new subspecies, Dugesia japonica ryukyensis subspec. nov. Bull. Fuji Wom. Coll., 14 (2): 81-126.

Kawakatsu, M., S. Tamura, T. Yamayoshi \& I. Oki, 1980. The freshwater planarians from Thailand and South India. Annotationes zool. jap., 53: 254-268.

KENK, R., 1930a. Euplanaria cretica Meixner, eine Triklade mit eigentümlichen Drüsenorgan. Zool. Anz., 92: 247-253.

-_, 1930b. Beiträge zum System der Probursalier. Zool. Anz., 89: 145-162, 289-302.

-, 1974 . Index of the genera and species of the freshwater triclads (Turbellaria) of the world. Smithson. Contr. Zool., 183: 1-90.

KomareK, J., 1925. Die O. Schmidt'schen Süsswassertricladen von Corfu und Cephalonia, gesammelt von Professor Wilhelmi. Zool. Anz., 63: 322-328.

Kosswic, C. \& F. Battalgil, 1942. Zoogeographie der türkischen Süsswasserfische. Revue Fac. Sci. Univ. Istanbul, 7: 145-165.

- \& -, 1943. Beiträge zur türkischen Faunengeschichte, I. Süsswasserfische. Revue Fac. Sci. Univ. Istanbul, 8: 18-63.

LePori, N. G., 1947. Descrizione di Dugesia monoadenodattila, nuova razza di Planaria di acque dolce. Monitore zool. ital., 56: 35-44.

- , 1948. Descrizione di Dugesia ilvana n. sp. di planaria di acqua dolce dei dintorni di Catania. Archo. zool. ital., 33: 183-193.

-_, 1951. Sulle caratteristiche morfologiche e sulla posizione sistematica della planaria di Sardegna e Corsica gia ascritta a Dugesia (Euplanaria) gonocephala (Dugès). Atti Soc. tosc. Sci. nat., 58B: 28-47.

Livanov, N. A., 1951. Planarians of Kopet-Dag, and related species from Crimea, Caucasia and Transcaucasia. Trudy Murgabsk. Gidrobiol. St., 1: 103-114. [In Russian.] 
Marcus, E., 1953. Turbellaria Tricladida. Explor. Parc natn. Upemba Miss. G. F. de Witte, 21: 1-62.

- , 1955. Turbellaria. Explor. Parc natn. Garamba Miss. H. de Saeger, 3: 1-31.

Meixner, J., 1928. Der Genitalapparat der Tricladen und seine Beziehungen zu ihrer allgemeinen Morphologie, Phylogenie, Ökologie und Verbreitung. Z. Morph. Ökol. Tiere., 11: 570-612.

Natasescu, M., 1972. Dugesia cretica (Meixner) 1928, specie noua pentru fauna Rumaniei. Studii Cerc. Biol., (Seria Zoologie) 24 (6): 513-519.

SснміDт, O., 1861. Untersuchungen über Turbellarien von Corfu und Cephalonia nebst Nachtragen zu früheren Arbeiten. Z. wiss. Zool., 11: 1-30, pls. 1-4.

VRIEs, E. J. DE I. R. Ball, 1980. On Dugesia gonocephala from western Europe. Bijdr. Dierk., 50: 342-350.

Wilhelmi, J., 1908. Sinnesorgane der Auriculargegend bei Süsswassertricladen. Zool. Anz., 33 (12): 388-393.

Young, J. O. B. M. Young, 1974. The distribution of freshwater triclads (Platyhelminthes; Turbellaria) in Kenya and Tanzania, with ecological observations on a stream-dwelling population. Zool. Anz., 193: 350-361.

Received: 13 April 1984 